
$138 / 3 / 80.5$.

\title{
ENERGY-ENVIRONMENTAL IMPACTS \\ OF FIVE ENERGY CONSERVATION MEASURES \\ IN THE MIDDLE ATLANTIC AND PACIFIC STATES
}

\author{
P.D. Moskowitz, E. Edelson, T.Q. Le, W.A. Sevian, \\ J.E. SMIth, AND A. Struth
}

October 1979

Prepared for the

DIVISION OF TECHNOLOGY ASSESSMENTS

OFFICE OF TECHNOLOGY IMPACTS

OFFICE OF THE ASSISTANT SECRETARY FOR ENVIRONMENT UNITED STATES DEPARTMENT OF ENERGY

NATIONAL CENTER FOR ANALYSIS OF ENERGY SYSTEMS

DEPARTMENT OF ENERGY AND ENVIRONMENT

BROOKHAVEN NATIONAL LABORATORY

UPTON, NEW YORK 11973 


\section{DISCLAIMER}

This report was prepared as an account of work sponsored by an agency of the United States Government. Neither the United States Government nor any agency Thereof, nor any of their employees, makes any warranty, express or implied, or assumes any legal liability or responsibility for the accuracy, completeness, or usefulness of any information, apparatus, product, or process disclosed, or represents that its use would not infringe privately owned rights. Reference herein to any specific commercial product, process, or service by trade name, trademark, manufacturer, or otherwise does not necessarily constitute or imply its endorsement, recommendation, or favoring by the United States Government or any agency thereof. The views and opinions of authors expressed herein do not necessarily state or reflect those of the United States Government or any agency thereof. 


\section{DISCLAIMER}

Portions of this document may be illegible in electronic image products. Images are produced from the best available original document. 
BNL 51110

UC-95a

This book was prepared as an accouml of work sponsored by an agency of the United States Government. Neither the United Stales Government nor any agency thered, nor any of their emplovees. makes any

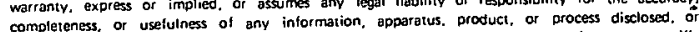

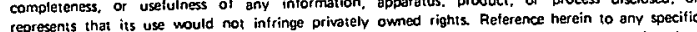

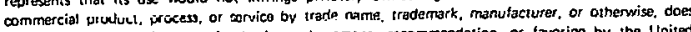
not necessorily constiture or imply its endorsement, recommendation, or favoring by the United States Government of any agency thereof. The views and opinions of authors expressed

necessarily state or reflect those of the United Stetes Government or any agency thereor.

\title{
ENERGY-ENVIRONMENTAL IMPACTS OF FIVE ENERGY CONSERVATION MEASURES IN THE MIDDLE ATLANTIC AND PACIFIC STATES
}

\author{
P.D. Moskowitz, E. Edelson, ${ }^{*}$ T.Q. LE, W.A. Sevian, \\ J.E. SMITH, AND A. STRUTH
}

October 1979

*Pacific Northwest Laboratories, Richland, Washington.

RESEARCH SPONSORED BY THE DIVISION OF TECHNOLOGY ASSESSMENTS

OFFICE OF TECHNOLOGY IMPACTS

OFFICE OF THE ASSISTANT SECRETARY FOR ENVIRONMENT UNITED STATES DEPARTMENT OF ENERGY

NATIONAL CENTER FOR ANALYSIS OF ENERGY SYSTEMS DEPARTMENT OF ENERGY AND ENVIRONMENT

BROOKHAVEN NATIONAL LABORATORY

ASSOCIATED UNIVERSITIES, INC.

UPTON, NEW YORK 11973

UNDER CONTRACT NO. DE-ACO2-76CH00016 WITH THE

UNITED STATES DEPARTMENT OF ENERGY 


\section{DISCLAIMER}

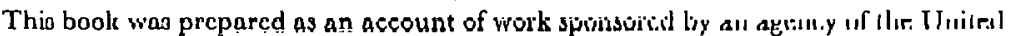
States Govcrnment. Ncithcr the Unitcd States Government nur any agency thereof, nor any of their emplnyers, makes any warranty, rypress or implied, ar assumrs a ny legal liability or responsibility for the accuracy, completeness, or usefulness of any information, apparatus, product, or process disclosed, or represents that its use would not infringe privately owncd rights. Reference herein to any specific commercial product, process, or service by trade name, trademark, manufacturer, or otherwise, dnes not necessarily constitute or imply its endorsement, recommendation, or favoring by the United States Government or any agency thereof. The views and opinions of authors expressed herein do not necessarily state or reflect those of the United States Government or any agency thereof.

Printed in the United States of America Available from

National Technical Information Service

U.S. Department of Commerce

5285 Port Royal Road

Springfield, VA 22161

Price: Printed Copy

$$
\text { G. }
$$




\section{ABSTRACT}

Estimates of some energy and environmental impacts for five different energy conservation measures (district heating, industrial cogeneration, retrofit, rate reform, and vehicle redesign) were prepared for two different regions (Middle Atlantic and Pacific) and two different time periods (1985 and 2000) based upon data presented in regional reference energy systems developed at Brookhaven National Laboratory. Results of the analysis indicate that regional energy use can be reduced by $<1$ to $6 \%$. Vehicle redesign produces the greatest oil savings. Retrofit and district heating can each reduce oil and natural gas use. Industrial cogeneration can significantly reduce use of fuels consumed in central station electricity production (e.g., coal and nuclear) but at an energy penalty incurred by industry: increased dependence on oil and natural gas could result. Rate reform and retrofit each reduce emissions production in rough proportion to the quantities of energy saved. Vehicle redesign reduces only supply sector emissions; end-use emissions are not affected even though gasoline use significantly decreases. District heating may reduce regional emissions but increase local emission burdens where waste heat is being produced. Local air quality need not be adversely affected, although long-range transport potential increases. The district heating concept may also have important effects on future power plant siting options. Depending on the mix of fuels consumed, industrial cogeneration could increase regional emissions production because of the potential substitution of dirty fuels (coal, industrial wastes, and oil) for clean fuels (natural gas and nuclear); this may be particularly important in the Pacific region. In general, per unit reductions in electrical demand appear to produce greater environmental benefits than equivalent reductions in fuels used directly in an end-use device. Minimizing energy use does not necessarily minimize the production of environmental emissions. 


\section{ACKNOWLEDGMENTS}

We thank Bee-Lian Chen for computer programing assistance and Barbara Pierce for data analysis. We are indebted to Robert Blaunstein, Vary Coates, Fred Lipfert, Peter Meier and David Moses for their constructive guidance and comments provided throughout all phases of this effort. We also wish to thank Connie Barnard-Murray, Betty Burke, Laine Harris McCarthy, and Patricia Miller for their assistance. This work was supported by the Divison of Technology Assessments, Office of Technology Impacts, Office of the Assistant Secretary for Environment, U.S. Department of Energy, under contract EY-76-C-02-0016. 


\section{CONTENTS}

Abstract...........................................

Acknowl edgments................................... iv

1 Conclusions and Recommendations......................... 1

2 Introduction....................................... 4

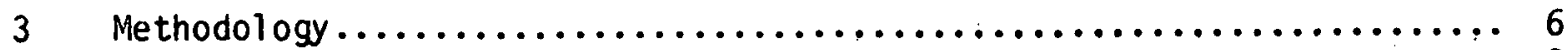

3.1 Base Case Regional Reference Energy System.................. 9

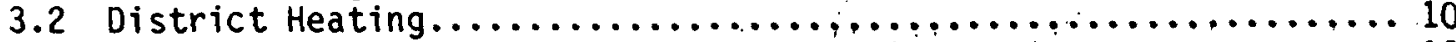

3.2.1 District Heating - Base Case Estimates................ 10

3.2 .2 District Heating - Low Case Estimates................ 11

3.2.3 District Heating - High Case Estimates............... 11

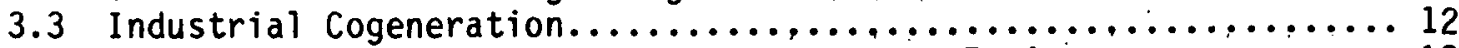

3.3.1 Industrial Cogeneration - Base Case Estimates........... 12

3.3.2 Industrial Cogeneration - Low Case Estimates............. 13

3.3.3 Industrial Cogeneration - High Case Estimates............ 14

3.3.4 Fuel s Used in Industrial Cogeneration................ 14

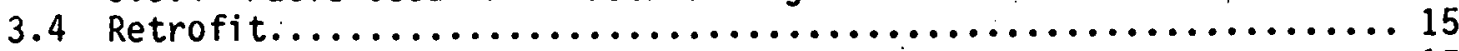

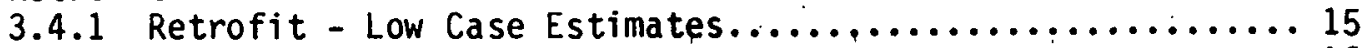

3.4.2 Retrofit - High Case Estimates................... 16

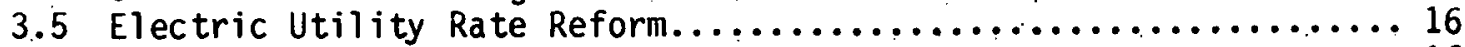

3.5.1 Rate Reform - Low and High Case Estimates.............. 16

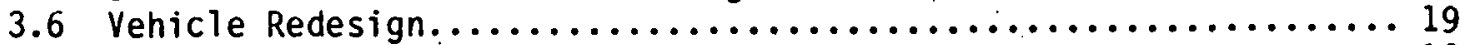

3.6.1 Vehicle Redesign - Low Case Estimates................. 19

3.6.2 Vehicle Redesign - High Case Estimates................ 19

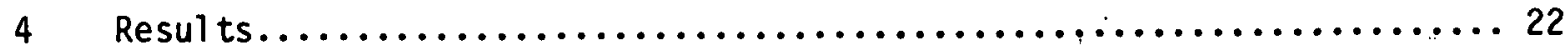

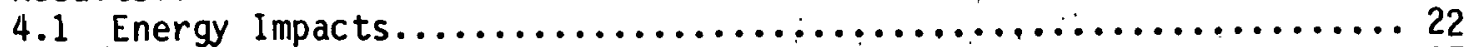

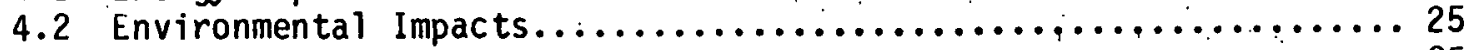

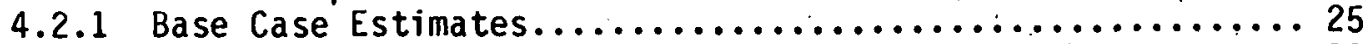

4.2 .2 Trajectory Estimates.......................... 30

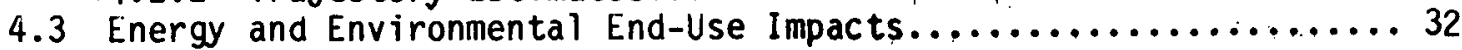

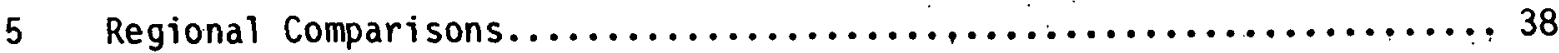

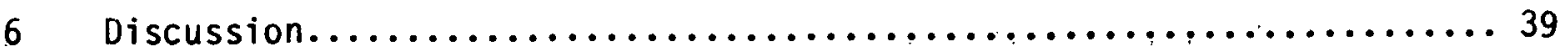

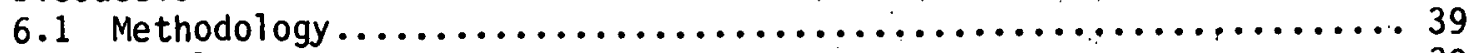

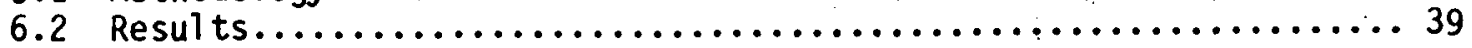

$7 \quad$ References....................................... 42

Appendix A. Calculations of Demand Reduction by Retrofit........... 45

Appendix B. Calculations of Demand Reduction by Rate Reform...........49 


\section{TABLES}

1 Residential/Commercial Heating Demands Supplied by District Heating,

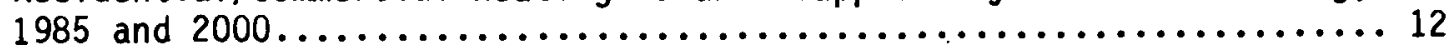

2 Basic Energy Demand in the Industrial Electric Drive and Process Heat Sectors Due to Industrial Cogeneration.................. 14

3 Reduction in Basic Energy Demand in Space Heat Due to Retrofit...... 17

4 Reduction in Basic Energy Demand in Air Conditioning Due to

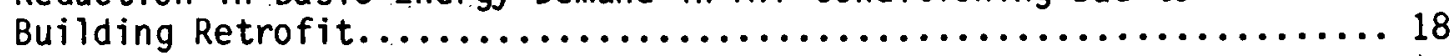

5 End-Use Electrical Energy Savings Due to Rate Reform............20

6 Projected Energy Savings Due to Vehicle Redesign.............. 21

7 Total Energy Resources Consumed - Middle Atlantic.............. 23

8 Total Energy Resources Consumed - Pacific.................. 24

9 Sites of Electricity Generation - Middle Atlantic............. 26

10 Sites of Electricity Generation - Pacific.................... 27

11 Environmental Residual Estimates - Middle Atlantic..............28

12 Environmental Residual Estimates - Pacific.................... 29

13 Base Case Environmental Residual Estimates - Sector Contributions.... 31

14 District Heating End-Use Impacts - Middle Atlantic............. 33

15. District Heating End-Use Impacts - Pacific.................. 34

16 Industrial Cogeneration End-Use Impacts - Middle Atlantic......... 35

17 Industrial Cogeneration End-Use Impacts - Pactfic................. 36 


\section{CONCLUSIONS AND RECOMMENDATIONS}

Environmental impacts imposed by different energy conservation measures have escaped the intense public scrutiny undergone by other technologies because of the widespread belief that conservation produces only benefits. Potential costs and benefits, however, must be rigorously evaluated for the formulation of wise and workable public policies. In response to this need, research was initiated to rigorously assess the potential effects of saving energy on the production of environmental residuals. The Regional Reference Energy System developed at Brookhaven National Laboratory was used as a framework to estimate energy and environmental impacts for five different conservation measures (district heating, industrial cogeneration, retrofit, rate reform, and vehicle redesign) in two different regions (Middle Atlantic and Pacific) at two different times $(1985$ and 2000$)$. Initial results of this analysis suggest the following:

A. Regional energy use can be reduced by $<1$ to $6 \%$.

B. Potential savings in 2000 are generally greater than in 1985 because of changes the market penetration of each alternative.

c. The effect on overall fuel consumption by fuel type varies with the technology used. District heating and retrofit reduce primarily the use of oil and natural gas. Industrial cogeneration significantly reduces fuel use in central station electricity production (coal, natural gas, nuclear) but may increase use of scarce fuels (oil and natural gas) at the sites of industrial combustion. Rate reform affects all fuels used for central station electricity production. Vehicle redesign affects only the use of oil.

D. Vehicle redesign offers the best opportunity for reducing regional use of oil. Retrofit and district heating also reduce oil use and have the greatest potential for reducing natural gas use. Industrial cogeneration may have the greatest potential for reducing nuclear and coal use in the Middle Atlantic region and nuclear and natural gas consumption in the Pacific region.

E. Cogeneration of electricity and process or space heat can significantly reduce regional energy use but may have important effects in shifting future sites of electricity generation. This may affect the quantities and mix of fuels consumed and of restduals produced and may also aftect siting options and emission control strategies. 
F. All the measures except industrial cogeneration reduce environmental residuals production in the region.

G. Rate reform, because it reduces electricity utility supply emissions, can provide important regional environmental benefits.

H. Retrofit may significantly reduce end-use area source emissions from residential/commercial furnaces. In urban areas with marginal air quality, this may be particularly important.

I. Waste heat utilization via district heating may produce significant regional benefits by reducing area source emissions, but its costs to the local environment may be significant: for example, it could increase sulfur oxide and nitrogen oxide emissions and it could also increase land use and solid waste disposal requirements. Because of differences in meteorological dispersion characteristics between area and point-source emissions, district heating could still improve local air quality even though increasing end-use emissions; however, it could increase long-range transport potential and mean weighted population exposures to air pollutants. At present the Clean Air Act encourages new power plant construction at sites remote from population demand centers, but district heating plants must be located near their potential customers; this gives rise to an interesting dichotomy. Future power plant siting strategies are likely to be affected by the district heating concept.

J. Industrial cogeneration can have far-reaching effects by altering future energy use patterns in different regions. Because this may affect not only fuel options but also the environment, the potential long-term consequences must be considered. Cogeneration facilities may pose greater environmental threats than electricity generating plants because they may emit more pollutants per Btu consumed. Increased use of industrial cogeneration can also affect future siting options by shifting electricity production from large central station plants to smaller decentralized facilities. The different location of these plants is likely to affect control strategies and subsequent exposure patterns and to increase the difficulty of policing and regutation.

K. Vehicle redesign does not affect end-use emissions, even though gasoline consumption is significantly reduced, because present federal standards link emissions to vehicle miles traveled rather than to miles per gallon. It may, however, reduce refinery emissions. 
L. Minimizing energy use does not necessarily minimize environmental emissions. Minimization of residuals production requires concurrent evaluation of both supply-demand energy efficiencies and fuel types consumed. When efficiency is increased and use of "dirty" fuels (e.g., coal) decreased, emissions are minimized. In general, a reduction in electrical demand appears to produce greater benefits per unit than an equivalent reduction of fuels used directly in an end-use device, because of the relative inefficiency of the electricity supply technology.

M. Because of the basic fuel use patterns in the electric utilities, reductions in electric supply requirements in the Middle Atlantic region will produce greater benefits per unit then equivalent reductions in the Pacific region.

N. In the Middle Atlantic region, application of industrial cogeneration technology is not likely to produce significant changes in regional environmental quality, whereas, in the Pacific region, it could cause adverse effects due to the substitution of "dirty" fuels for "clean" fuels.

0 . Each independent alternative is expected to have fairly modest overall energy and environmental benefits. The combined benefits of all these alternatives over a large number of years may be quite significant. 


\section{INTRODUCTION}

Patterns and trends of energy use within the United States are undergoing intensive scrutiny so that the most efficient strategies for reducing the overall consumption of energy can be determined. The goal of most studies is to minimize energy use at the least cost. Assessments of the impacts of energy conservation strategies have thus traditionally focused on the overall energy benefits and consequent savings in dollar costs. The environmental effects of these strategies, though seldom assessed rigorously, are generally thought to be beneficial; therefore, energy conservation technologies have escaped the intense public scrutiny undergone by other technologies and strate gies, Potential environmental benefits, costs, or uncertainties associated with the implementation of energy conservation strategles must be fully uinderstood, however, for wise and workable public policies to be formulated.

In response to this need, the Assistant secretary for Enviruniluent, Department of Energy, initiated a series of studies designed to evaluate and compare a number of promising energy conservation measures in terms of their potential impacts on the environment, on human communities, and on national objectives and policies.

One phase of this overall effort was a quantitative exploration of the interactions between changing energy use patterns and the concomitant change in various environmental parameters; this report presents the results. Since the study was exploratory, only a limited number of energy conservation measures were evaluated. The effects of five such measures on environmental parameters in two census regions in the U.S., the Middle Atlantic and the Pacific regions, were reviewed for the years 1985 and 2000 . Low and high estimates of the energy impacts were prepared for each conservation measure to determine the range of possible consequences. The five measures assessed were district heating, industrial cogeneration, retrofit of existing residential and commercial buildings, utility rate reform strategies, and redesign of the private automobile to increase fuel economy. These were selected on the basis of information gathered at. a workshop sponsored by Brookhaven National Laboratory (BNL) in April 1979,1 which was another phase of the overall effort. Each measure offers substantial potential for energy savings; taken together they affect all major energy using sectors (residential, industrial, commercial, transportation, and utility) and present a spectrum of implementation strategies and of possible environmental and social constraints and opportunities. 
The basic unit chosen for analysis was the region because detailed data are available on energy use by fuel type and process at that geographic level of dissaggregation and because it was of interest to determine whether significant variations between regions would be found. The Pacific* and Middle Atlantic*t regions were selected because of the regional expertise of the participating laboratories, BNL in the Middle Atlantic region and Pacific Northwest Laboratories in the Pacific region.

Actual environmental impacts, e.g., changes in population exposures to sulfates, were not assessed. Instead, first-order approximations of the environmental costs and benefits imposed by the different conservation strategies were developed by using estimates of expected emissions as a surrogate for actual damage. Included in this analysis are estimates of the effects of each technology on regional air pollutant emissions, solid waste production, 1 and use, and some health and safety impacts.

«Pacific region includes Alaska, Washington, Oregon, and California. **Middle Atlantic region includes New York, New Jersey, and Pennsylvania. 


\section{METHODOLOGY}

The Regional Reference Energy System (RRES) ${ }^{2}$ and the Models for EnergyEnvironmental Residuals Analysis-1 (MEERA-1) model 3,4 developed at BNL were used in these analyses to provide formal structure in determining the energy and environmental impacts of particular energy conservation strategies. The RRES is a network representation of the technical activities required to supply various forms of energy to end-use activities (Figure 1). Technologies are defined for all operations involving specific fuels including resource extraction, refinement, conversion, transporation, distribution, and utilization. Fach activity is represented by a link in the network for which an efficiency is specified. The network is quantified for a given year with the levels of energy demands and the energy flows through the supply activities that are required to serve these demands: The RRES thus provides an accounting methodology for the energy flows through the system.

The model, as implied, is demand driven; that is, the intermediate energy forms appearing in the RRES between centralized conversion and utilization are initially computed for residential, commercial, industrial, and transportation end-use devices. These demands are then fed back into the system to determine the specific supply requirements by fuel type. The MEERA-1 model serves both as the data source for the supply technology energy efficiencies and the environmental emissions coefficients (see discussion below) and as snftware for the analyses.

In the RRES, the demands are estimated from a large number of documented assumptions based on region-specific data. In the residential and commercial sectors, for example, energy requirements for a particular end-use demand (e.g., space heating) are computed. for each region as a function of fuel demand per household, number of households, and saturation of a particular end-use device (e.g., air-conditioning units). In the industrial sector, energy use is disaggregated into the major energy-intensive Industries including aluminum, iron, stepl, and petrochemiçals, and the remaining industrial energy use is imcluded under industrial process heat and industrial electric devices. Transportation sector energy demands are broken down by transportation mode (e.g., automobile, plane, ship). For automobiles, energy consumption is based on a composite fleet-averaged fuel efficiency derived for each reference year on the basis of mix of model years on the road, distribution of vehicle-miles traveled by age of automobile, fuel efficiency by model year, 


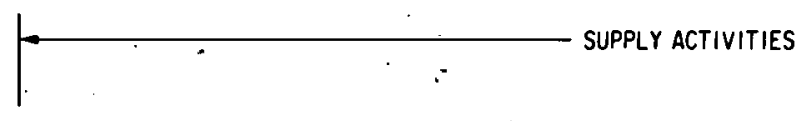

- UtILIzation activities $\longrightarrow$

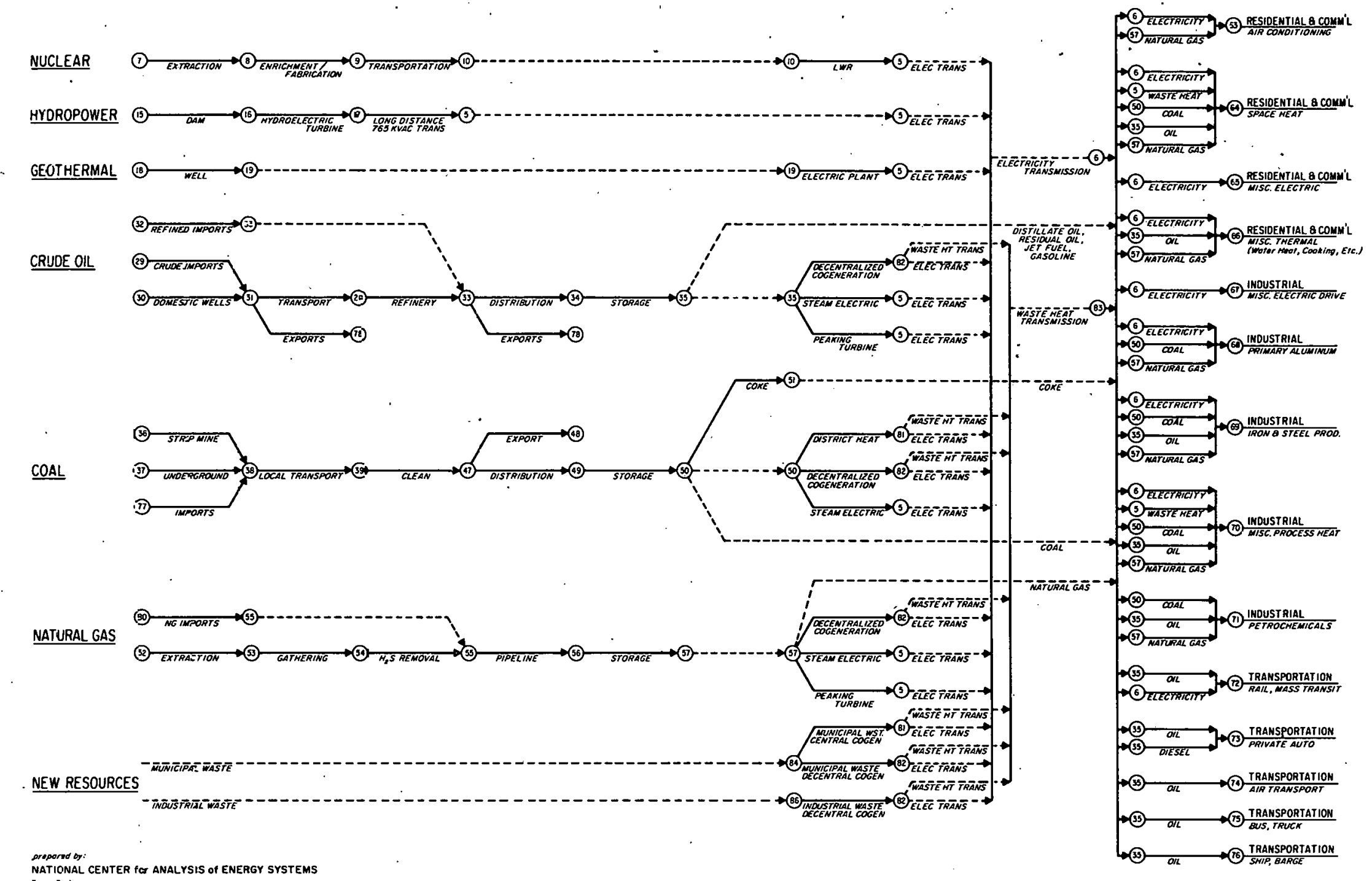

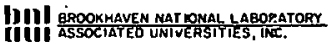

Figure 1. Regional Reference Energy System Network. 
and estimated total vehicle-miles traveled. Underlying each demand sector is a large set of region-specific data, described in greater detail by Hermelee. 2

By reviewing and modifying these data, it is easy to examine technologyspecific perturbations quantitatively and to trace their impacts on the system as a whole. For example, reduced end-use demands for residential space heating result in lower requirements for oil, natural gas, and electricity generation requirements, which in turn, reduce the supply sector requirements. Similarly, increased industrial cogeneration of electricity as a by-product of process heat production reduces central station electricity generation requirements: this is called a utility credit. The energy impacts of both the change in end-use dellidids for process hical and the utility crondit can subsequently be traced. Since end-use demands are derived on the basis of specific quantitative assumptions cuncerring technologlcs cmployed, the effiritency of the end-use device in question, etc., a rigorous quantitative study of the regional energy impacts of an improvement in efficiency (e.g.,retrofit) or introduction of a new technology (e.g., district heating) can readily be made. Indeed, since the RRES also includes specific regional data on energy use by fuel type, the framework allows for consistent specification of the energy system's impact not only on overall energy use, but also on specific fuels such as gas or oil.

Associated with each energy activity are residual coefficicnts defining air pollutants, solid wastes, 1 and use, and some health and safety impacts. All coefficients are specified in units of poliutant output per unit of eneryy input for each process (e.g., the emission factor for sulfur dioxide is given for a coal-fired boiler in units of tons of $\mathrm{SO}_{2}$ emitted per $10^{12}$ Btu of coal burned in the plant). To generate the energy required by each activity, one need only specify (1) the end-use demands in units of Blu dilivered by a fuclspecific end-use device, (fi) efriciency coefficicnts for all activities, i.e.. the ratio of energy output to energy input for both supply and end-use processes, and (iii) share values assigned to competing supply activities that specify the percentage of energy that each activity must deliver. Once the energy requirements are determined, the MEERA-1 model uses environmental coefficients to compute the total outputs of residuals by activity, by residual shown on a fuel type versus activity array, and by the complete run. The emission coefficients used in this analysis have been described in detai ${ }^{5}$ and are available from BNL. 6 


\subsection{BASE CASE REGIONAL REFERENCE ENERGY SYSTEMS}

In this analysis, Pacific and Middle Atlantic region base case demands and allocations were taken from Hermelee. ${ }^{2}$ Data underlying these bases were reviewed and subsequently modified to incorporate the appropriate changes required for each alternative. Perturbations of these base cases are meant only to serve as a guide to identify the possible range of impacts created by each al ternative; many different energy futures can be envisioned.

In the Middle Atlantic region, in both base cases, oil is the principal fuel used to meet the region's energy demand, although its relative share decreases from 1985 to 2000, and coal is the second largest source of raw energy. The other sources are hydropower, natural gas, and nuclear power, whose share grows significantly between 1985 and 2000. In the Middle Atlantic region base cases, electricity production consumes $33 \%$ of all fuels supplied in 1985 and $47 \%$ in 2000, with coal as the principal fuel in 1985 and nuclear energy in 2000. At the point of end use, the residential/comercial and industrial sectors each use roughly $45 \%$ of the fuels consumed and the transportation sector uses the remainder, with automobiles and airplanes as major users.

The Pacific region also depends on oil supplies as its principal fuel source but uses natural gas and hydropower as the second largest sources of energy. The energy contribution of nuclear power, though relatively small in 1985, is expected to increase substantially by 2000. In contrast to the Middle Atlantic region, the Pacific region uses coal for only a small percentage of $i$ ts demands in both years and expects some power from geothermal sources. Central station electricity production consumes $\sim 26 \%$ of the fuels used in 1985 and $38 \%$ in 2000, with hydropower, natural gas, and nuclear supplies (rather than coal) as the principal energy sources. Of the oil supplied, $\sim 10 \%$ is used for electricity generation and $90 \%$ for direct end-uses, mainly automobile and air transport and residential/commercial space heating. Natural gas is used for both electricity production ( 25\%) and process and space heating (75\%). Most of the coal consumed is used for electricity generation $(\sim 66 \%)$ and industrial process heat $(\sim 34 \%)$.

More details of both these trajectories are described by Hermelee. ${ }^{2}$ The assumptions used in explicitly defining some base case demands, in modifying both end-use demands and allocations for the five different measures are discussed below. 


\subsection{DISTRICT HEATING}

District heating technology is defined as one in which residential and commerical customers are provided with waste heat from nearby central station electricity generating plants. Shown below are the efficiencies and flows of energy through the district heating plant used in these analyses. This model is based on work by Karkheck et al.7

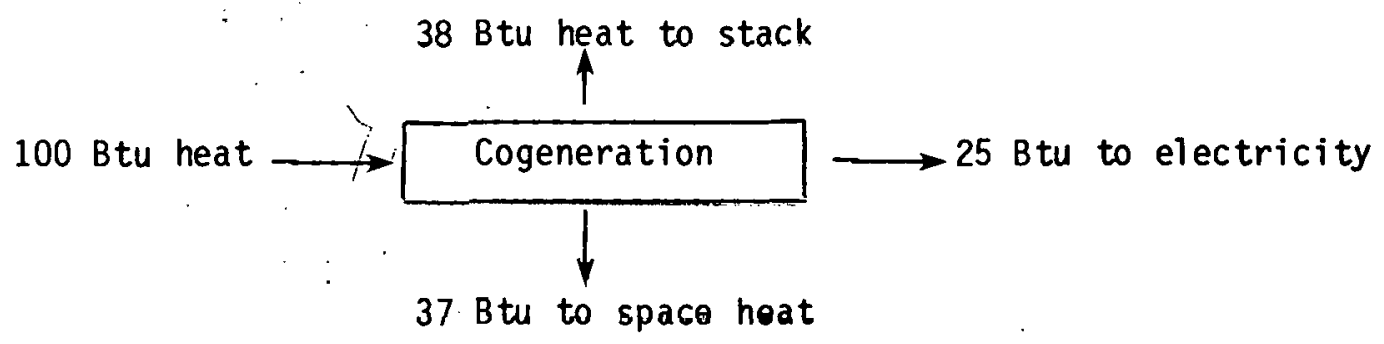

\subsubsection{District Heating - Base Case Estimates}

The most significant district heating system in the Middle Atlantic census region* is in New York City. This system, operated by Consolidated Edison Company, supplies steam through 80 miles of underground mains to 2900 customers, with about $70 \%$ of the total going to commercial and industrial establishments. More than 1.4 million people work or live in buildings heated with this steam. About $50 \%$ of the steam is generated by steam-only plants, $40 \%$ by topping cycle generators, and the rest by low pressure boilers that can be used for either. steam or electricity generation. Total energy use in steam generation by the system was estimated to be $63 \times 10^{12}$ Btu in 1970 . Currently, no expansion of the steam system is planned for the foreseeable future. 8

To determine the basic energy demand $(H)$ for residential and comercial space heat by district heating technology in the Middle Atlantic region in the base case, the following assumptions are made:

a. $50 \%$ of the current district heating capacity in Now York City is cogenerated.

b. The conversion efficiency of cogeneration is $62 \%$.

c. Current district heating capacity in New York lity represents $80 \%$ of total district heating in the region.

d. The current district heating system will not be expanded in the future.

* Because the RRES estimates are based on census regions rather than federal regions, we are obliged to use the census region for analysis even though most DOE planning is based on the federal region. 
Thus, $H$ for the base case for both 1985 and 2000 is:

$$
H_{\text {base }}=63 \times 10^{12} \mathrm{Btu} \times 0.5 \times 0.62 \times \frac{1}{0.80}=24 \times 10^{12} \mathrm{Btu} .
$$

Since no significant district heating capacity is in use or expected in the foreseeable future in the Pacific region, no district heating activity in this region for both the base and the low case estimates is assumed.

\subsubsection{District Heating - Low Case Estimates}

The National Energy Plan includes a number of measures designed to address some of the regulatory and institutional barriers to waste heat utilization. The federal goverment is supporting a vigorous R\&D program to demonstrate and develop cogeneration systems and related technologies. 9

In view of these policies, an arbitrary. figure of $3 \%$ annual growth rate is used for lower bound estimates in the Middle Atlantic region. This gives * district heating estimates in 1985 and 2000 as:

$$
\begin{aligned}
& H_{1 \text { ow-1985 }}=H_{\text {base }} \times(1.03)^{1985-1979}=24 \times 10^{12} \times(1.03)^{6}=29 \times 10^{12} \mathrm{Btu} \\
& \mathrm{H}_{1 \text { ow-2000 }}=H_{\text {base }} \times(1.03)^{2000-1979}=24 \times 10^{12} \times(1.03)^{21}=45 \times 10^{12} \mathrm{Btu}
\end{aligned}
$$

\subsubsection{District Heating - High Case Estimates}

High case estimates for district heating potential are developed by surveying patterns of energy use within the utility sector and the feasibility of using waste heat from these plants to meet district heating needs. Nuclear, oil- and natural gas-fired electric power plants are discarded as possible sources of district heat cogeneration: nuclear plants, on the grounds that any change from conventional design may complicate the already complex licensing process to an intolerable degree and that the existing political climate limits the use of nuclear power; 011 - and gas-fired power plants because of the growing need to reduce U.S. dependence on these fuels.

This leaves coal-fired electricity generating plants as the only major energy source for district heating. Here another constraint is that the location of an electricity generation plant must not be too far (more than 15 miles) from its district heating customers since heat loss through distribution pipe networks can be substantial over long distances. Forecasts from the

BNL power plant siting model,10 indicate that about $60 \%$ of the coal steam electric capacity in the Middle Atlantic region will be within a Standard 
Metropolitan Statistical Area in 2000. With the further assumption that half of this capacity is located sufficiently near urban centers, the estimates for district heating cogeneration maximum potential for the Middle Atlantic region are as follows:

$H_{\text {high-1985 }}=797 \times 10^{12} \mathrm{Btu} \times 0.6 \times 0.5=239 \times 10^{12} \mathrm{Btu}$;

$\mathrm{H}_{\text {high }-2000}=1227 \times 10^{12} \mathrm{Btu} \times 0.6 \times 0.5=368 \times 10^{12} \mathrm{Btu}$.

With similar assumptions, the maximum case estimate for district heating potential in the Pacific region is as follows:

$\mathrm{H}_{\text {high-1985 }}=72 \times 10^{12} \mathrm{Btu} \times 0.6 \times 0.5=22 \times 10^{12} \mathrm{Btu}$;

$H_{\text {hlgh }}-2000=201 \times 10^{12}$ Btu $\times 0.6$ and $0.5=61 \times 10^{13} \mathrm{Btu}$.

These estimates are summarized in Table 1.

\subsection{INDUSTRIAL COGENERATION}

Industrial cogeneration is defined as the on-site generation of both electricity and process heat by industry. Is is assumed that the thermal efficiency and the ratio of electricity to process heat production are the same as in the case of district heating.

\subsubsection{Industrial Cogeneration - Base Case Estimates}

Early in this century most industrial plants in the U.S. generated their own electricity with coal-fired boilers and steam-turbine generators, and many used the exhaust steam for industrial processes. Industry gradually shifted from generating electricity to purchasing it from a power plant. By 1950, on-site industrial generation accounted for only $15 \%$ of total U.S. electrical generation and, by 1974, about 5\%.11

For the base case, it is assumed for both the Middle Atlantic and the Pacific regions that $4 \%$ of total power generated in 1985 , and $3 \%$ in 2000 , will

\section{Table 1}

Residential/Commercial Space Heating Demands Supplied by District Heating, 1985 and 2000 (1012 Btu)

\begin{tabular}{|c|c|c|c|c|c|c|}
\hline \multirow[b]{2}{*}{ Sector and region } & \multicolumn{3}{|c|}{1985} & \multicolumn{3}{|c|}{2000} \\
\hline & Base & Low & $\mathrm{High}$ & Base & Low & High \\
\hline \multicolumn{7}{|l|}{ Residential/commercial } \\
\hline $\begin{array}{l}\text { Middle Atlantic } \\
\text { Pacific }\end{array}$ & $\begin{array}{r}24 \\
0\end{array}$ & $\begin{array}{r}29 \\
0\end{array}$ & $\begin{array}{r}239 \\
22\end{array}$ & $\begin{array}{r}24 \\
0\end{array}$ & $\begin{array}{r}45 \\
0\end{array}$ & $\begin{array}{r}368 \\
61\end{array}$ \\
\hline
\end{tabular}


be from on-site industrial power plants. Of these plants, $50 \%$ will cogenerate both electricity and process heat. The basic calculations are shown below.

Let $E_{X}$ be the basic energy demand for electricity generated by industrial cogeneration in year $x$, then

$E_{\text {base-1985 }}=$ (basic energy demand in the electric utility sector in 1985) $\times 4 \% \times 50 \%$

$=1660 \times 10^{12}$ Btu $\times 0.04 \times 0.5=33 \times 10^{12}$ Btu (Middle Atlantic);

$\Rightarrow 1443 \times 10^{12}$ Btu $\times 0.04 \times 0.5=29 \times 10^{12}$ Btu (Pacific).

Similarly,

$E_{\text {base-2000 }}=$ (basic energy demand in the electric utility sector in 2000) $\times 3 \% \times 50 \%$

$=3462 \times 10^{12}$ Btu $\times 0.03 \times 0.5=52 \times 10^{12}$ Btu (Middle Atlantic);

$=2226 \times 10^{12}$ Btu $\times 0.03 \times 0.5=33 \times 10^{12}$ Btu (Pacific).

\subsubsection{Industrial Cogeneration - Low Case Estimates}

The National Energy Plan includes a number of measures designed to promote cogeneration. Specifically, the plan proposes that

o industrial cogenerators be exempt from federal and state public utility regulations;

- the Federal Energy Regulatory Commission be required to establish procedures to ensure fair rates for the sale of excess power and the purchase of backup power;

o an investment tax credit of $10 \%$ (in addition to the current $10 \%$ tax credit) be available for the purchase of cogeneration equipment;

0 industrial firms and utilities investing in cogeneration equipment be exempt from the requirement to convert from oil and gas to coal if an exemption is necessary for cogeneration to be economically feasible. 9

For the low case estfmate, it is assumed for each region that electricity generation by industrial cogeneration will amount to $8 \%$ of the total electricity generated in 1985 and $10 \%$ in 2000.

Thus,

$E_{10 w-1985}=$ (basic energy demand in the electric utility sector in 1985) $\times 8 \%$

$=1660 \times 10^{12}$ Btu $\times 0.08=133 \times 10^{12}$ Btu (Middle Atlantic);

$=1443 \times 10^{12}$ Btu $\times 0.08=115 \times 10^{12}$ Btu (Pacific).

$E_{10 w-2000}=$ (basic energy demand in the electric utility sector in 2000 ) $\times 10 \%$

$=3462 \times 10^{12} \mathrm{Btu} \times 0.10=346 \times 10^{12} \mathrm{Btu}$ (Middle Atlantic);

$=2226 \times 10^{12}$ Btu $\times 0.10=223 \times 10^{12}$ Btu (Pacific). 


\subsubsection{Industrial Cogeneration - High Case Estimates}

A study prepared for the U.S. Federal Energy Administration 12 indicates that the maximum economic potential for cogeneration for six major industrie in the U.S. by 1985 would be 371.4 to 738.4 billion kWh of electrical energs produced. This is equivalent to a maximum of $20 \%$ of the total electricity generated in the U.S. in 1985 in the base case.

Thus, for the high case estimate, the amount of electricity generated by industrial cogeneration in each region is assumed to be $20 \%$ of the total electricity generated in that region in 1985 and in 2000 .

$E_{\text {high-1985 }}$ (basic energy demand in the electric utility sector in 1985) $\times 20 \%$ $=1660 \times 10^{12} \mathrm{Btu} \times 0.20=332 \times 10^{12} \mathrm{Btu}$ (Middle Atlantic);

$=1443 \times 1012 \mathrm{Btu} \times 0.20=228 \times 10^{12}$ Btu (Pacitic).

$E_{\text {high-2000 }}$ (basic energy demand in the electric utility sector in 2000) $\times 20 \%$ $=3462 \times 10^{12}$ Btu $\times 0.20=692 \times 10^{12}$ Btu (Middle Atlantic); $=2226 \times 10^{12}$ Btu $\times 0.20=445 \times 10^{12}$ Btu (Pacific).

The above estimates are summarized in Table 2.

\subsubsection{Fuels Used in Industrial Cogeheration}

Natural gas, oil, coal, and many liquid and solid industrial wastes have been used as fuel in industrial boilers. About $40 \%$ of the total energy used in the pulp and paper industry was derived from the combustion of wood wastes and spent pulping liquors in 1972.13

For this study, it is assumed that in the Middle Atlantic region the ruel mix used in cogeneration will consist (un an energy basis) of coal (3.9\%), natural gás $(24 \%)$, oil (22\%), and industrial wastes (15\%). Except for indus-

\begin{tabular}{|c|c|c|c|c|c|c|}
\hline $\begin{array}{l}\text { Basic Energy De } \\
\text { Process Heat Secto }\end{array}$ & $\begin{array}{l}\text { Tat } \\
\text { the } \\
\text { to In }\end{array}$ & $\begin{array}{l}2 \\
\text { idustr } \\
\text { istria }\end{array}$ & $\begin{array}{l}\text { Elect } \\
\text { ogener }\end{array}$ & $\begin{array}{l}\text { ic Dri } \\
\text { tion }\end{array}$ & $\begin{array}{l}\text { and } \\
2 \text { B tu }\end{array}$ & \\
\hline & & 1985 & & & 2000 & \\
\hline Sector and desian & Baso & Low & Ili g̈li & Bdse & Low & High \\
\hline $\begin{array}{l}\text { Residential/cumucrical } \\
\text { space heat }\end{array}$ & & & & & & \\
\hline $\begin{array}{l}\text { Middle Atlantic } \\
\text { Pacific }\end{array}$ & $\begin{array}{l}33 \\
29\end{array}$ & $\begin{array}{l}133 \\
115\end{array}$ & $\begin{array}{l}332 \\
288\end{array}$ & $\begin{array}{l}52 \\
33\end{array}$ & $\begin{array}{l}346 \\
223\end{array}$ & $\begin{array}{l}692 \\
445\end{array}$ \\
\hline $\begin{array}{c}\text { Industrial process heat } \\
\text { Middle Atlantic } \\
\text { Pacific }\end{array}$ & $\begin{array}{l}49 \\
43\end{array}$ & $\begin{array}{l}197 \\
170\end{array}$ & $\begin{array}{l}491 \\
426\end{array}$ & $\begin{array}{l}77 \\
49\end{array}$ & $\begin{array}{l}512 \\
330\end{array}$ & $\begin{array}{r}1024 \\
659\end{array}$ \\
\hline
\end{tabular}


trial wastes, the fuels are in the same proportions as in the industrial process heat fuel mix defined in the 1985 base case by Hermelee.2 In the Pacific region it is assumed that the fuel mix will be equally divided among industrial wastes, natural gas, and oil, each providing one-third of the energy.

\subsection{RETROF IT}

The energy impact of building retrofit is to reduce energy demand for residential and commerical space heating and air conditioning. Retrofit measures may also affect energy demand for hot water, but this is ignored here because the energy savings potential is relatively small.

\subsubsection{Retrofit - Low Case Estimates}

The recent rise in costs of electricity, home heating oil, and gas has led to widespread retrofitting of buildings. The Council on Environmental Qual ity 14 reported, "Industry data showed that 2-3 million households added an average of 4-5 inches of attic insulation during 1974 and 1975 . . . Occupants of 10 million single-family detached homes took actions to add energy-saving features in 1975. The average household spends $\$ 150$ for attic insulation, wall insulation, storm windows, caulking, and/or weather stripping."

One of the objectives of the National Energy Act of 1978 is "weatherization of $90 \%$ of the homes in the country by 1985."15 since this percentage probably includes new homes, which are excluded in this assessment, and since the low case is intended to be conservative, it is assumed that $70 \%$ of buildings existing in 1980 * would be retrofitted by 2000 . Note that the inventory of retrofitted buildings in year 2000 takes into account buildings retired by that year. Thus the basic equation is

$\begin{gathered}\text { Inventory of retrofitted } \\ \text { buildings in } 2000\end{gathered}=\begin{gathered}\text { inventory of existing } \\ \text { buildings in } 1980\end{gathered} \times 0.7 \times(1-R)$

where $R$ is the building removal rate for the 1980 to 2000 period. $R$ varies according to building type and region (see Appendix $A$ ).

BNL calculations 16 indicated that an average savings of $30 \%$ per unit could be achieved in single-family homes in the Northeast by retrofitting; to be conservate, an average of $20 \%$ is assumed in the low case scenario.

*The cutoff point between existing and new buildings is 1980 because that is the effective date for the federal thermal standards for new buildings proposed in the President's energy plan. 29 
The estimates for reduction in basic energy demand for space heat and air conditioning due to retrofit for the Middle Atlantic and Pacific regions are shown in Tables 3 and 4 . The detailed data used to develop these estimates are presented in Appendix A.

\subsubsection{Retrofit - High Case Estimates}

For the high case estimates it is assumed that up to $95 \%$ of buildings existing in 1980 will be retrofitted by 2000 . The equation for inventory of retrofitted buildings in this case is:

$\begin{gathered}\text { inventory of retrofitted } \\ \text { buildings in } 2000\end{gathered}=\begin{gathered}\text { inventory of existing } \\ \text { buildings in } 1980\end{gathered} \times 0.95 \times(1-R)$.

Also the average savings per retrofitted housing unit is assumed to be $30 \% .16$ Details of the calculations are given in Appendix A. The results of the calculations are shown in Tables 3 and 4.

\subsection{ELECTRIC UTILITY RATE REFORM}

The rate reform conservation al ternative is defined as a movement towards marginal or replacement cost pricing and away from average cost pricing. The short-term impact of marginal cost pricing is expected to be a reduction in overall electricity demand. In the long run, alternative pricing schemes will result in dynamic sets of changes including changes in appliance stock, use of insulation, generating mix, etc. To simplify the present analysis and provide crude estimates of the benefits produced by these rate initiatives, only short-term impacts have been considered, and long-term effects have been neglected because of their complexity. This measure differs from the others in that it requires modeling of behavioral reactions rather than of a technically engineered response, but the overall task requires only reasonable estimates of the impacts for analytic purposes.

\subsubsection{Rate Reform - Low and High Case Estimates}

On the basis of work done at Oak Ridge Natfonal Laboratory, 17 both low and high case estimates were developed by modeling electricity consumption as a function of the price elasticity for electricity, the percentage change in electricity prices as rate reform schedules are implemented, and estimates of existing levels of electricity consumption derived from the RRES.

Using data specific to the region (Middle Atlantic and Pacific) and sector (residential/commercial and industrial) for 1985 and 2000, impacts on overall electricity demand were estimated. Since available data below the 
Table 3

Reduction in Basic Energy Demand in Space Heat Due to Retrofit (1012 Btu)

\begin{tabular}{|c|c|c|c|c|c|c|c|c|}
\hline \multirow[t]{3}{*}{ Building type and fuel type } & \multicolumn{4}{|c|}{ Mid-Atlantic } & \multicolumn{4}{|c|}{ Pacific } \\
\hline & \multicolumn{2}{|c|}{$1985^{a}$} & \multicolumn{2}{|c|}{$2000^{b}$} & \multicolumn{2}{|c|}{$1985^{C}$} & \multicolumn{2}{|c|}{$2000^{b}$} \\
\hline & Low & High & Low & High & Low & High & Low & High \\
\hline $\begin{array}{l}\text { Residential } \\
\text { Mobile home } \\
\text { Single-family, detached } \\
\text { Single-family, attached } \\
\text { Multi-family, low rise } \\
\text { Multi-family, high rise } \\
\text { Commercial } \\
\text { Total residential/commercialc } \\
\text { Natural gas } \\
\text { Oil } \\
\text { Electricity }\end{array}$ & $\begin{array}{c}0.42 \\
43.3 \\
6.3 \\
3.15 \\
2.66 \\
48.8 \\
105 \\
33.5 \\
60.7 \\
10.5\end{array}$ & $\begin{array}{c}0.84 \\
88.4 \\
12.8 \\
6.44 \\
5.39 \\
99.3 \\
213 \\
68.2 \\
124 \\
21.3\end{array}$ & $\begin{array}{c}0.60 \\
61.9 \\
9.00 \\
4.50 \\
3.80 \\
69.7 \\
150 \\
47.8 \\
87.0 \\
15.0\end{array}$ & $\begin{array}{c}1.20 \\
126.3 \\
18.3 \\
9.20 \\
7.70 \\
142 \\
304 \\
97.5 \\
177 \\
30.4\end{array}$ & $\begin{array}{c}0.20 \\
17.0 \\
2.30 \\
0.60 \\
0.50 \\
20.7 \\
41.4 \\
22.8 \\
6.70 \\
12.0\end{array}$ & $\begin{array}{c}0.50 \\
34.7 \\
4.70 \\
1.30 \\
1.00 \\
42.2 \\
84.4 \\
46.4 \\
13.5 \\
24.4\end{array}$ & $\begin{array}{c}0.30 \\
24.3 \\
3.30 \\
0.90 \\
0.70 \\
29.6 \\
59.1 \\
32.5 \\
9.50 \\
17.1\end{array}$ & $\begin{array}{c}0.70 \\
49.6 \\
6.70 \\
1.80 \\
1.40 \\
60.3 \\
120 \\
66.3 \\
19.3 \\
.34 .9\end{array}$ \\
\hline
\end{tabular}

aAssumed to be $70 \%$ of the raductions in 2000 .

betermined by multiplying unit reductions in basic energy demand in space heat (Table 2) by numbers of retrofit units in. 2000 (see Appendix A).

CShares of energy reduction by fuel type are assumed to be the same as the fuel mix of regional residential and commercial space heat basic energy demands in 1980 . Thus the respective shares of natural gas, oil, and electricity are: $32 \%, 58 \%, 10 \%$ for the Middle Atlantic region and 55\%, 16\%, 29\% for the Pacific region. 


\begin{tabular}{|c|c|c|c|c|}
\hline \multicolumn{5}{|c|}{$\begin{array}{c}\text { Reduction in Basic Energy Uemand in Air-Conditioning } \\
\text { Due to Building Retrofit }\left(10^{12} \mathrm{Btu}\right)\end{array}$} \\
\hline \multirow[b]{2}{*}{ Region, sector, and fuel type } & \multicolumn{2}{|c|}{1985} & \multicolumn{2}{|c|}{2000} \\
\hline & Low & High & Low & High \\
\hline $\begin{array}{l}\text { Middle Atlantic } \\
\text { Rusidullial } \\
\text { Roun AC } \\
\text { Central AC } \\
\text { Cuniliercidl } \\
\text { Total residential/commercialc } \\
\text { Electricity } \\
\text { Natural gas }\end{array}$ & $\begin{array}{c}2.92 \\
3.53 \\
9.97 \\
16.4 \\
15.6 \\
0.81\end{array}$ & $\begin{array}{c}5.94 \\
7.20 \\
20.3 \\
33.4 \\
31.8 \\
1.66\end{array}$ & $\begin{array}{c}4.17 \\
5.05 \\
14.2 \\
3.46 \\
22.6 \\
0.89\end{array}$ & $\begin{array}{c}8.48 \\
10.38 \\
29.0 \\
47.8 \\
46.0 \\
1.81\end{array}$ \\
\hline $\begin{array}{l}\text { Pacific } \\
\text { Residential } \\
\text { Room } A C \\
\text { Central AC } \\
\text { Commercial } \\
\text { Total residential/conmercialC } \\
\text { Electricity }\end{array}$ & $\begin{array}{l}1.54 \\
4.33 \\
14.4 \\
20.2 \\
19.4\end{array}$ & $\begin{array}{l}3.15 \\
8.80 \\
29.3 \\
41.3 \\
39.5\end{array}$ & $\begin{array}{l}2.20 \\
6.19 \\
20.5 \\
28.9 \\
28.0\end{array}$ & $\begin{array}{l}4.50 \\
12.6 \\
41.9 \\
59.0 \\
57.0\end{array}$ \\
\hline \multicolumn{5}{|c|}{$\begin{array}{l}\text { botermined by multiplying unit reductions in basic energy demands in air } \\
\text { conditioning by numbers of air conditioners in retrofitted buildings (see } \\
\text { Appendix A). }\end{array}$} \\
\hline \multicolumn{5}{|c|}{$\begin{array}{l}\text { CShares of reduction in basic energy demand in air conditioning are assumed to } \\
\text { be the same as the fuel mix of basic energy demand in air conditioning in the } \\
\text { appropriate year and region, namely } 0.95 / 0.05 \text { for electricity/natural gas for } \\
\text { both regions in } 1985 \text { and } 0.96 / 0.04 \text { in } 2000 \text {. }\end{array}$} \\
\hline
\end{tabular}


sectoral level are not very comprehensive, only sector level estimates were used to calculate energy saved. The assumptions and approaches used are discussed in Appendix $B$, and the basic results are summarized in Table 5.

\subsection{VEHICLE REDESIGN}

Ways to improve the fuel economy of private automobiles include production of lighter and smaller cars, body and engine redesign, etc. In this analysis, it is assumed that all these factors will undergo changes to improve the average fleet economy in each new model year. In all three cases discussed below the number of automobiles is assumed to be the same. In the high case a $10 \%$ increase in vehicle-miles traveled is assumed because of data found in the literature. These numbers are slightly modified from data presented by Hermel ee. 2

\subsubsection{Vehicle Redesign - Low Case Estimates}

The Energy Policy and Conservation Act of 1975 . (EPCA) requires that beginning in 1978 the average fuel economy of each car manufacturer's new car fleet meet the minimum fuel economy standards. The standards start at $18 \mathrm{mpg}$ for 1978 and reach $27.5 \mathrm{mpg}$ in 1985.18 The EPCA requirement, coupled with recent high gasoline prices and shortages, has led to the current trends toward an increasing share of small cars in the market and improved fuel efficiency in larger cars. The EPCA requirements might even be surpassed: General Motors, for example, said the 1985 model cars would exceed the mandated fleet average of $27.5 \mathrm{mpg}$ because of the shift in consumer attitudes towards more fuel-efficient automobiles. 19

With EPCA fuel economy standards used, the average low case fleet fuel economy is $19.0 \mathrm{mpg}$ for 1985. No fuel economy standards have been set beyond 1985, but fleet fuel economy in 2000 is arbitrarily assumed to be $30 \mathrm{mpg}$. These data and the base cases are shown in Table 6 .

\subsubsection{Vehicle Redesign - High Case Estimates}

In the high case, a rapid increase in the share of small cars in the total fleet is assumed, as well as marked improvements in the fuel economy of automobiles of all sizes. The share of small cars is assumed to be $75 \%$ in 1985 and $90 \%$ in 2000. The average fuel economies of small and 1arge cars are assumed to be 25 and $15 \mathrm{mpg}$ for 1985, and 40 and $20 \mathrm{mpg}$ for 2000 . A $10 \%$ increase in vehicle-miles traveled is assumed in the high cases. The impact of these changes on fuel use is al so shown in Table 6 . 


\section{Table 5}

End-Use Electrical Energy Savings

Uue to fiate -Reform $\left(\times 10^{12}\right.$ Btu $)$

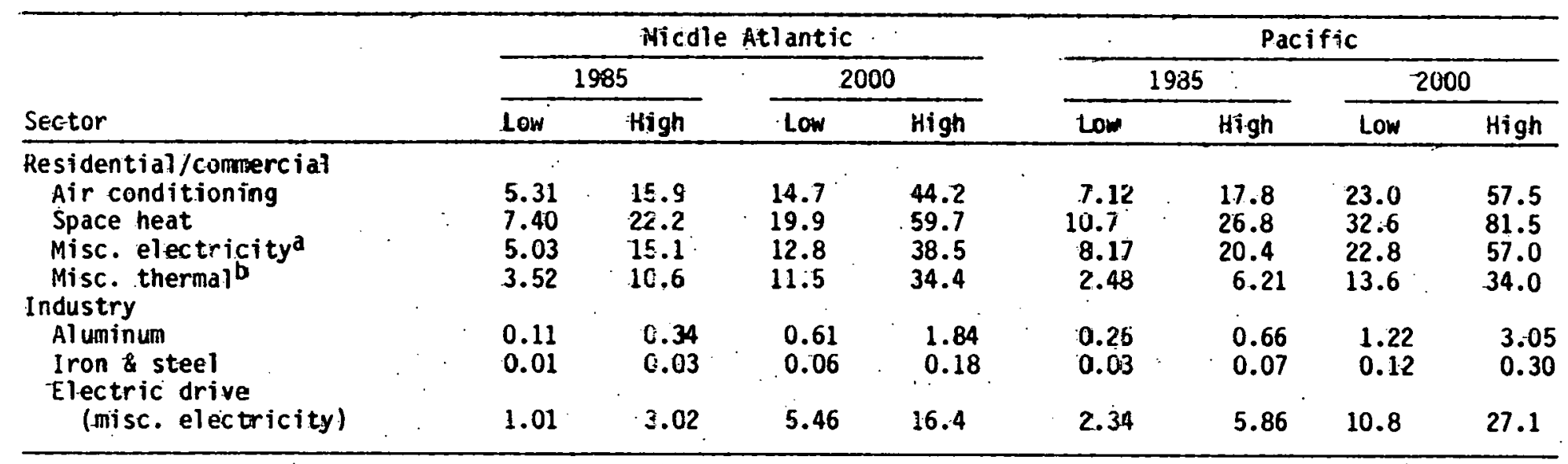

amiscellaneous electricity includes appliances and lighting.

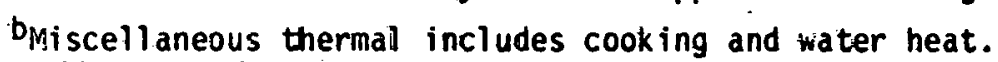


Table 6

Projected Energy Savings Due to Vehicle Redesign

\begin{tabular}{|c|c|c|c|c|c|c|c|}
\hline \multirow[b]{2}{*}{ Assumptions } & \multicolumn{4}{|c|}{1985} & \multicolumn{3}{|c|}{2000} \\
\hline & 1972 & Base & Low & High & Base & Low & $\mathrm{High}$ \\
\hline $\begin{array}{l}\text { Av. fuel fleet } \\
\text { economy (mpg) }\end{array}$ & $13.5^{\mathrm{a}}$ & $16.1^{b}$ & $19.0^{C}$ & $22.5^{d}$ & 18.0 & 30.0 & $38.0^{\mathrm{e}}$ \\
\hline $\begin{array}{l}\text { Mileage per auto } \\
\text { per year }\end{array}$ & $10,200^{f}$ & $11,650^{f}$ & $11,650^{f}$ & 12,8209 & $13,740^{\mathrm{C}}$ & $13,740^{f}$ & 11,110 \\
\hline $\begin{array}{l}\text { Percent of small } \\
\text { autos in fleet }\end{array}$ & $2.9^{h}$ & --- & --- & 75.0 & --- & 75.0 & 90.0 \\
\hline $\begin{array}{l}\text { fleet (106) } \\
\text { Vehicle-miles/yrj } \\
\text { Gasol ine usek } \\
\text { (1012 Btu/yr) }\end{array}$ & $\begin{array}{r}96.6^{i} \\
986.42\end{array}$ & $\begin{array}{r}116.0^{i} \\
1351.40\end{array}$ & $\begin{array}{c}116.0 \\
1351.40\end{array}$ & $\begin{array}{c}116.0 \\
1487.16\end{array}$ & $\begin{array}{r}133.3^{i} \\
1831.54\end{array}$ & $\begin{array}{c}133.3 \\
1831.54\end{array}$ & $\begin{array}{c}133.3 \\
2014.16\end{array}$ \\
\hline $\begin{array}{l}\text { National } \\
\text { Mid-Atlantic } \\
\text { Pacific }\end{array}$ & $\begin{array}{l}9133.52 \\
1315.23 \\
1264.08\end{array}$ & $\begin{array}{r}10492.22 \\
1510.87 \\
1452.12\end{array}$ & $\begin{array}{l}8890.79 \\
1280.27 \\
1230.48\end{array}$ & $\begin{array}{l}9261.77 \\
1189.69 \\
1132.42\end{array}$ & $\begin{array}{r}12719.03 \\
1831.54 \\
1760.31\end{array}$ & $\begin{array}{l}7631.41 \\
1098.92 \\
1056.18\end{array}$ & $\begin{array}{r}6625.52 \\
954.07 \\
916.97\end{array}$ \\
\hline
\end{tabular}

aFEA. 201972 data are included for comparison.

bFEA estimate, at oil price of $\$ 4 /$ bbl (constant 1973 price). (FEA, 20 Project Independence and Energy Conservation: Transportation Sectors, 1974.)

CAssuming that average fleet fuel economy in 1985 would be that required by EPCA for new car fleet in 1980, i.e., $19 \mathrm{mpg}$; and for 2000, that required by EPCA for new car fleet in 1985.

dDeduced by assuming that $75 \%$ of auto fleet comprises small cars with av. mpg of 25 , and $25 \%$ of fleet comprises larger cars with av. mpg of 15.

e Assuming that $90 \%$ of auto fleet comprises small cars with av. mpg of 40 , and $10 \%$ of fleet comprises larger cars with av. mpg of 20 .

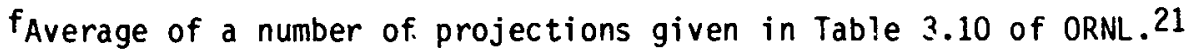

gAssumed to be $10 \%$ higher than for base case on the basis that, as fuel economy is improved, drivers would drive more.

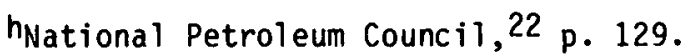

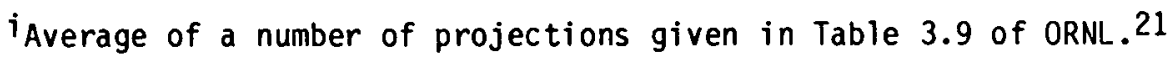

jDetermined by multiplying miles traveled per auto by total number of autos. Data for Middle Atlantic and Pacific regions in 1985 and 2000 are determined by assuming that they have the same fractions as in 1976 .

$k_{\text {Assuming energy content of gasoline is } 125,000 \mathrm{Btu} / g a l \text {. Regional fractions }}$ of gasoline consumption are assumed to be the same as in 1976, i.e., $14.40 \%$ of national total for Middle Atlantic and $13.84 \%$ for Pacific.

1 Hermelee. 2 


\section{RESULTS}

\subsection{ENERGY IMPACTS}

The impacts of modifying both end-use demands (e.g., retrofit) and central station electricity generation allocations (e.g., industrial cogeneration vs. central station generation) on overall energy use patterns within the Middle Atlantic and Pacific regions are summarized in Tables 7 and 8 . In general the conservation measures assessed can be expected to reduce regional energy use by $<1$ to $6 \%$. The projected savings in 2000 generally exceed those in 1985 because of increased penetration of each measure. This analysis indicates that industrial cogeneration produces the greatest overall savings in energy use in both years. Savings due to the other technologies differ in the different years, depending on the sector and end-use demands affected.

All the measures provide net benefits in terms of reductions in overall energy use, but the impact by fuel type varies according to the demands modified by each measure. District heating primarily reduces the use of oil and natural gas to provide residential and commercial space heat. It also reduces demand for electricity production, and this utility credit is given only to coal-fired generating capacity; thus, district heating also reduces coal use. Industrial cogeneration reduces central station electricity capacity requirements at an energy cost incurred at the point of industrial end use. Thus, the consumption of fuels used for central station generation (principally coal and nuclear in the Middle Atlantic region, and natural gas and nuclear in the Pacific region) decreases at a concurrent cost to the consumption of fuels used for industrial cogeneration (industrial waste, coal, oil, and natural gas). After accounting for all the changes in fuels, efficiencies, and points of combustion, the model predicts at the regional level an absolute decrease in all fuels consumed except for natural gas in the Middle Atlantic region and oil in the Pacific reqion. In the Middle Atlantic region, natural gas use increases from the base case because it is increasingly depended on by industry and is absent from central station generation (which is declining). In the Pacific region, a similar situation exists for oil. Retrofit and rate reform affect all fuels provided to the end-use activities (e.g., residential/commercial space heating) and end-use devices (e.g., electric heaters) involved. Retrofit reduces the use of electricity, $0 i 1$, and natural gas; rate reform reduces the use of electricity. Thus, the use of coal and nuclear fuel is decreased in the Middle Atlantic region and that of natural gas and nuclear fuel in the Pacific region. Vehicle redesign affects only oil usage. 


\section{Table 7}

Total Energy Resources Consumed, 1015 Btu

(Percent Reduction From Base Trajectory; Minus Sign Indicates Increase)

Middle Atlantic Region

\begin{tabular}{|c|c|c|c|c|c|c|c|c|c|c|c|}
\hline \multirow[b]{2}{*}{ Fuel type } & \multirow{2}{*}{$\begin{array}{l}\text { Base } \\
\text { case }\end{array}$} & \multicolumn{2}{|c|}{ Dist. heating } & \multicolumn{2}{|c|}{ Ind. cogeneration } & \multicolumn{2}{|c|}{ Retrofit } & \multicolumn{2}{|c|}{ Rate reform } & \multicolumn{2}{|c|}{ Vehicle redesign } \\
\hline & & Low & High & Low & High & Low & High & Low & High & Low & High \\
\hline & & & & & Trajectory - & -1985 & & & & 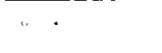 & \\
\hline Total & 14.69 & $14.68(<1)$ & $14.24(3)$ & $14.51(1)$ & $\begin{array}{l}14.17(4) \\
\text { Trajectory - }\end{array}$ & $\begin{array}{l}14.48(1) \\
-2000 \\
\end{array}$ & $14.21(3)$ & $14.56(1)$ & $14.43(2)$ & $14.45(2)$ & $14.35(2)$ \\
\hline $\begin{array}{l}\text { Coal } \\
\text { Petroleum } \\
\text { Natural gas } \\
\text { Nuclear } \\
\text { Hydroelectric } \\
\text { New resources } \\
\text { Geothermal }\end{array}$ & $\begin{array}{l}5.48 \\
9.11 \\
1.75 \\
5.46 \\
0.30 \\
0.02\end{array}$ & $\begin{array}{l}5.47(<1) \\
9.09(<1) \\
1.74(<1) \\
5.461) \\
0.30() \\
0.02()\end{array}$ & $\begin{array}{l}5.44(<1) \\
8.75(4) \\
1.58(10) \\
5.45(<1) \\
0.30() \\
0.02()\end{array}$ & $\begin{array}{l}5.25(4) \\
9.08(<1) \\
1.94(-11) \\
4.91(10) \\
0.30() \\
0.13(-550\end{array}$ & $\begin{array}{l}4.98(9) \\
9.05(<1) \\
2.17(-24) \\
4.27(22) \\
0.30() \\
0.26(-1200)\end{array}$ & $\begin{array}{l}5.46(<1) \\
8.93(20 \\
1.66(5) \\
5.43(<1) \\
0.30() \\
0.02()\end{array}$ & $\begin{array}{l}5.42(1) \\
8.72(4) \\
1.56(11) \\
5.39(1) \\
0.30() \\
0.02()\end{array}$ & $\begin{array}{l}5.31(3) \\
9.10(<1) \\
1.75() \\
5.34(2) \\
0.30() \\
0.02()\end{array}$ & $\begin{array}{l}5.16(6) \\
9.08(<1) \\
1.75() \\
5.10(6) \\
0.30() \\
0.02()\end{array}$ & $\begin{array}{l}5.48() \\
8.34(8) \\
1.75() \\
5.46() \\
0.30() \\
0.02()\end{array}$ & $\begin{array}{l}5.48() \\
8.20(10) \\
1.75() \\
5.46() \\
0.30() \\
0.02()\end{array}$ \\
\hline Total & 22.11 & $22.07(<1)$ & $21.53(3)$ & $21.61(2)$ & $21.01(5)$ & $21.79(1)$ & $21.41(3)$ & $21.81(1)$ & $21.41(3)$ & $21.35(3)$ & $21.20(4)$ \\
\hline
\end{tabular}


Table 8

Total Energy Resources Consumed, $10^{15}$ Btu

(Percent Reduction From Base Trajectory; Minus Sign Indicates Increase)

Pacific Region

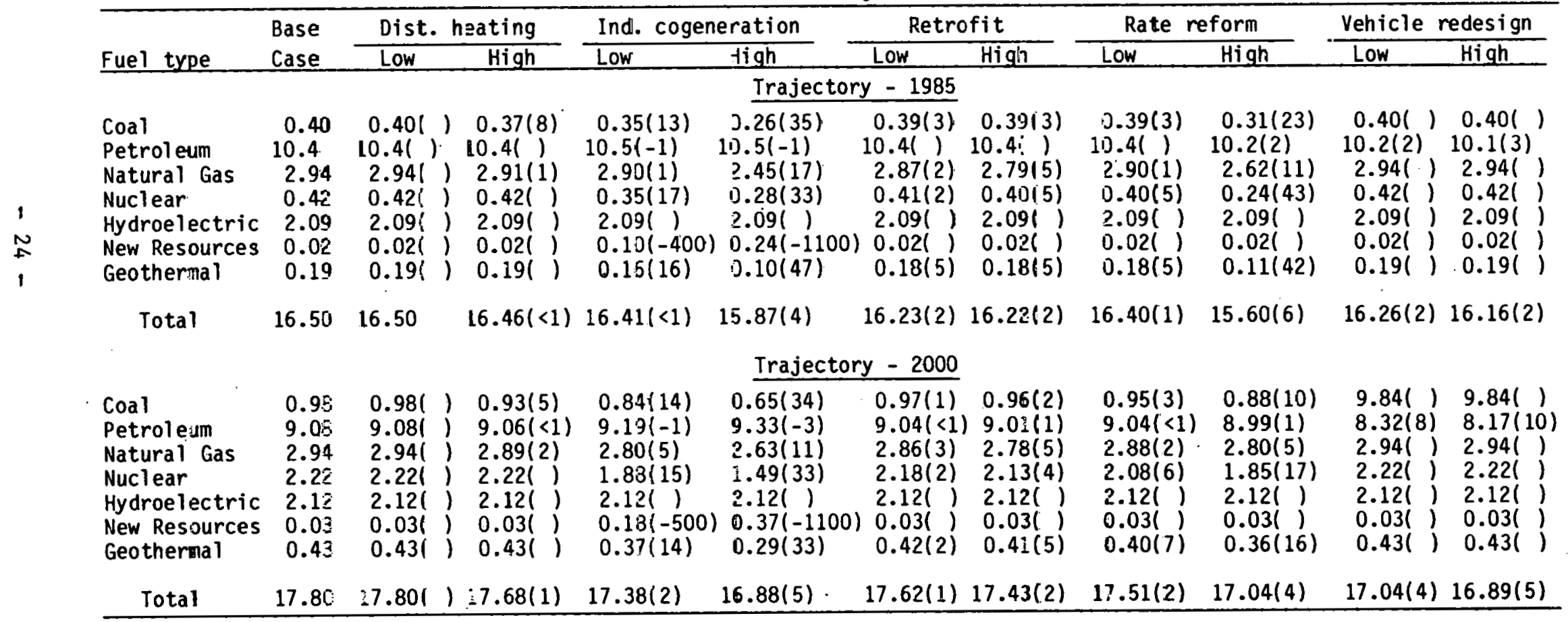


Vehicle redesign appears to produce the greatest savings in oil in both regions. Retrofit, district heating and rate reform have the greatest potential for reducing natural gas use. With the assumptions employed, industrial cogeneration appears to produce positive benefits in significantly reducing utility supply energy requirements though at a cost to natural gas use in the Middle Atlantic region and oil use in the Pacific region, which appear to increase. Industrial cogeneration also increases the use of industrial wastes. In this analysis, it is assumed that hydroelectricity capacity is unaffected by any of the strategies.

The impact of all these technologies on both the size and location. of central station electricity production is of interest. Tables 9 and 10 indicate that rate reform provides the best means of reducing overall electricity generating requirements; retrofit and district heating provide some decrease; and industrial cogeneration and vehicle redesign have no effect.

Waste heat utilization via district heating and industrial cogeneration does not significantly reduce electricity demand but can shift generating capacity from large centralized plants to smaller decentralized facilities. This shift may affect not only the quantity and mix of fuels burned but al so the environmental impacts. The smaller facilities, for example, may emit larger quantities of pollutants per Btu consumed and present greater control problems, and cost more per unit of electricity produced. Furthermore, because their locations may be significantly different from those of large central plants, they may produce significantly different environmental impacts. District heating plants need to be located near their demand centers whereas central plants may be located hundreds of miles away. This may be of critical concern, both to finding suitable sites for district heating plants and the impacts they may produce.

\subsection{ENVIRONMENTAL IMPACTS}

\subsubsection{Base Case Estimates}

Tables 11 and 12 include summaries of the environmental residual estimates for the Middle Atlantic and Pacific region base cases in 1985 and 2000. Increases in all emissions are expected for both base cases in 2000 due to growth in total energy demand and increased dependence on fossil fuels. The overall increases in emissions projected for 2000 are attenuated by expected increases in nuclear power use. This technology emits few of the conventional pollutants assessed and is thus considered to be comparatively "clean"; its 


\begin{tabular}{|c|c|c|c|c|c|c|c|c|c|c|c|}
\hline \multirow{2}{*}{\multicolumn{12}{|c|}{$\begin{array}{l}\text { Sites of Electricity Generation, } 10^{15} \text { Btu } \\
\text { (Percent Reduction from Base Case; Minus Sign Indicates Increase) }\end{array}$}} \\
\hline & & & & & & & & & & & \\
\hline \multirow[b]{2}{*}{ Site } & \multirow{2}{*}{$\begin{array}{l}\text { Base } \\
\text { Case }\end{array}$} & \multicolumn{2}{|c|}{ Dist. heating } & \multicolumn{2}{|c|}{ Ird. cogeneration } & \multicolumn{2}{|c|}{ Retrofit } & \multicolumn{2}{|c|}{ Rate reform } & \multicolumn{2}{|c|}{ Vehicle redesign } \\
\hline & & Low & High & Low & High & Low & High & Low & High & Low & High \\
\hline \multicolumn{12}{|c|}{ Trajectory - 1985} \\
\hline $\begin{array}{l}\text { Central station } \\
\text { electricity } \\
\text { generation }\end{array}$ & 1.44 & 1.44() & $1.18(18)$ & $1.34(7)$ & $1.14(21)$ & $1.43(1)$ & $1.41(2)$ & $1.42(1)$ & $1.38(4)$ & 1.44() & 1.44() \\
\hline $\begin{array}{l}\text { Cogeneration } \\
\text { district } \\
\text { Heating }\end{array}$ & 0.081 & $0.02 !)$ & $0.28(-1300)$ & C.02( ) & $0.02(\quad)$ & $0.02(1)$ & $0.02(1)$ & $0.02(1)$ & $0.02(1)$ & $0.02(1)$ & 0.02() \\
\hline $\begin{array}{l}\text { Cogeneration } \\
\text { process heat }\end{array}$ & 0.08 & $0.03 i$ & $0.031)$ & $0.13(-330)$ & $0.33(-1000$ & $0.03(1)$ & $.0 .03(1)$ & 0.0311 & $0.03(1)$ & $0.03(1)$ & $0.03(1)$ \\
\hline Totai & 1.49 & $1.49 !)$ & $1.46(2)$ & $1: 49()$ & 1.49() & $1.48(1)$ & 1.46121 & $1 .-47(1)$ & $1.43(4)$ & 1.49() & 1.49() \\
\hline \multicolumn{12}{|c|}{ Irajectory - 2000} \\
\hline $\begin{array}{l}\text { Central station } \\
\text { electricity } \\
\text { generation }\end{array}$ & 3.04 & $3.02:(1)$ & $2.71(117)$ & $2.75(10)$ & $-2.40(21)$ & $3.02(1)$ & $3.00(1)$ & $2.97(2)$ & $2.85(6)$ & $3.041+$ & 3.0411 \\
\hline $\begin{array}{l}\text { Cogeneration } \\
\text { district } \\
\text { heating }\end{array}$ & 0.02 & $0.03(-5))$ & $0.25(-1200)$ & $0.021)$ & $0.02(1)$ & $=0.021)$ & $0.021)$ & $0.02(1)$ & $0.02(1)$ & 0.0211 & $0.02(1)$ \\
\hline $\begin{array}{l}\text { Cogeneration } \\
\text { process heat }\end{array}$ & -0.05 & $-0.05 i$ & $0.051)$ & $-0.34(-580)$ & $0.69(-1300)$ & $0.05(1$ & $0.051)$ & $0.05(1)$ & 0.0571 & $0.05(1)$ & $0.05(1$ \\
\hline Total & 3.11 & 3.10 ? & $3.01(3)$ & $3.11(1)$ & $3.11(1)$ & $3.09(1)$ & $3.07(1)$ & $3.04(2)$ & $2.92(6)$ & 3.11() & $3.111)$ \\
\hline
\end{tabular}




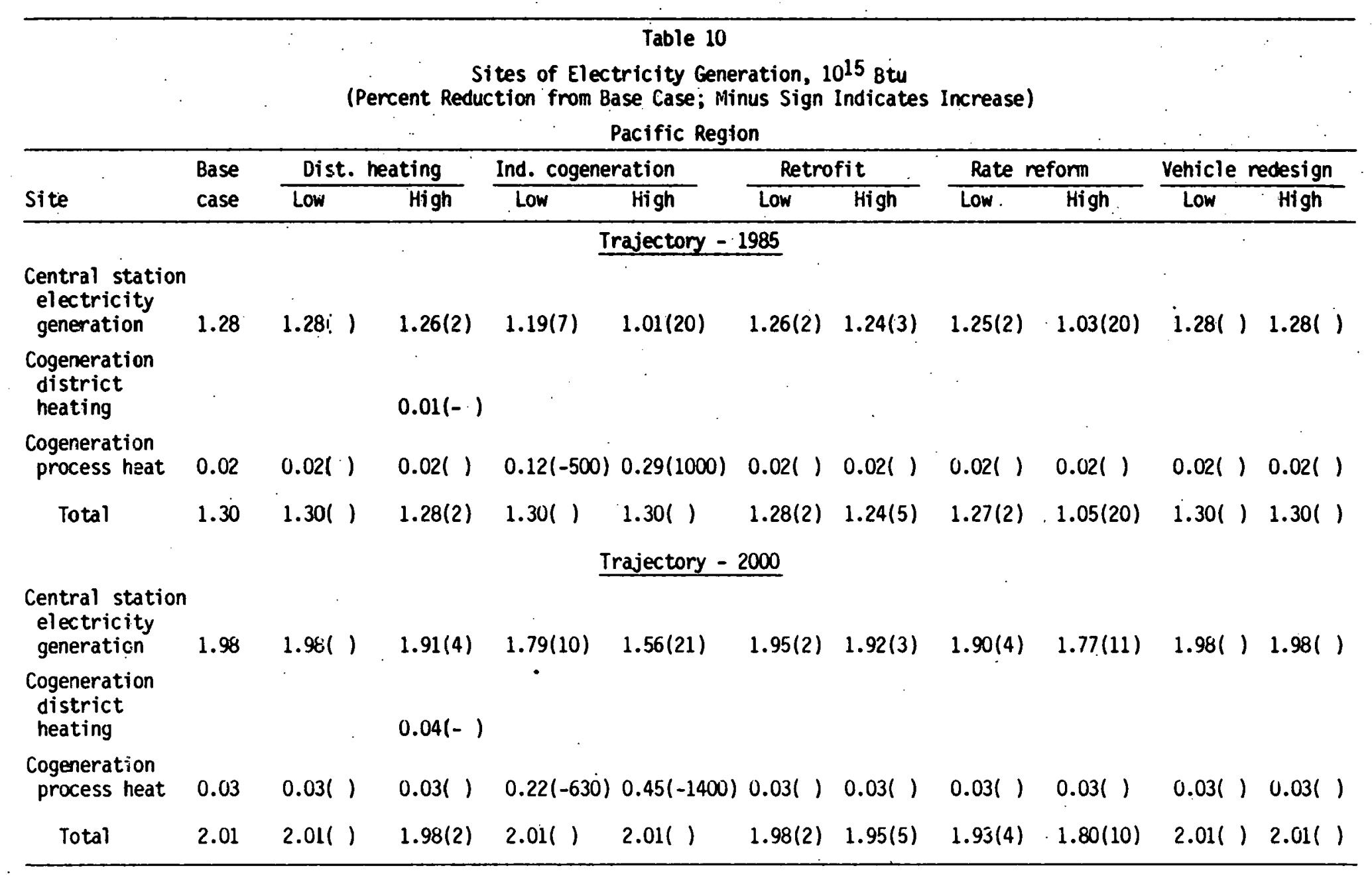


Table 11

Trajectory of Environmental Residual Estimates

(Percent Reduction From Base; Minus Șign Indicates Increase)

Middle Atlantic Region

\begin{tabular}{|c|c|c|c|c|c|c|c|c|c|c|c|}
\hline \multirow[b]{2}{*}{ Pollutants } & \multirow{2}{*}{$\begin{array}{l}\text { Base } \\
\text { case }\end{array}$} & \multicolumn{2}{|c|}{ Dist. heat. } & \multicolumn{2}{|c|}{ Ind. cogen. } & \multicolumn{2}{|c|}{ Retrofit } & \multicolumn{4}{|c|}{ Rate reform Veh. redesign } \\
\hline & & Low & High & $\overline{\text { Low }}$ & $\mathrm{High}$ & Low & High & Low & $\overline{\text { High }}$ & Low & High \\
\hline \multicolumn{12}{|c|}{ Irajectory - 1985} \\
\hline $\begin{array}{ll}\text { Air pollutants } & \left(10^{5} \mathrm{~T}\right) \\
\text { Particulates } & \left(10^{6} \mathrm{~T}\right) \\
\text { Nitrogen oxides } & \left(10^{6} \mathrm{~T}\right) \\
\text { Sulfur dioxide } & \left(10^{5} \mathrm{~T}\right) \\
\text { Hydrocarbons } & \left(10^{6} \mathrm{~T}\right) \\
\text { Carbon monoxide } & \left(10^{6} \mathrm{~T}\right) \\
\text { Carbon dioxide } & \left(10^{9} \mathrm{~T}\right)\end{array}$ & $\begin{array}{l}4.84 \\
2.81 \\
1.22 \\
6.12 \\
4.04 \\
0.88\end{array}$ & $\begin{array}{l}0 \\
0 \\
0 \\
0 \\
0 \\
0\end{array}$ & $\begin{array}{l}3 \\
2 \\
3 \\
1 \\
0 \\
4\end{array}$ & $\begin{array}{r}1 \\
-1 \\
4 \\
1 \\
0 \\
1\end{array}$ & $\begin{array}{r}3 \\
-3 \\
12 \\
2 \\
0 \\
3\end{array}$ & $\begin{array}{l}1 \\
1 \\
2 \\
0 \\
0 \\
2\end{array}$ & $\begin{array}{l}3 \\
2 \\
4 \\
1 \\
0 \\
4\end{array}$ & $\begin{array}{l}0 \\
0 \\
1 \\
0 \\
0 \\
0\end{array}$ & $\therefore \begin{array}{l}1 \\
1 \\
2 \\
0 \\
0 \\
1\end{array}$ & $\begin{array}{l}0 \\
0 \\
1 \\
0 \\
0 \\
0\end{array}$ & $\begin{array}{l}0 \\
0 \\
1 \\
1 \\
0 \\
0\end{array}$ \\
\hline Solid waste $\quad\left(10^{7} \mathrm{~T}\right)$ & 5.16 & 0 & 2 & 2 & 6 & 1 & 2 & 2 & 4 & 0 & 0 \\
\hline Land use $\quad\left(10^{6}\right.$ acres $)$ & 2.38 & 0 & 10 & 3 & 10 & 0 . & 1 & 1 & 2 & 0 & 0 \\
\hline $\begin{array}{l}\text { Occupational } \\
\text { health \& sa fety } \\
\text { Deaths (10 } 1 \text { persons) } \\
\text { Injuries }\left(10^{3} \text { persons) }\right. \\
\text { Man-days lost }\left(10^{5}\right)\end{array}$ & $\begin{array}{l}5.01 \\
5.74 \\
1.15\end{array}$ & $\begin{array}{l}0 \\
0 \\
0\end{array}$ & $\begin{array}{l}1 \\
1 \\
1\end{array}$ & $\begin{array}{l}3 \\
3 \\
3\end{array}$ & $\begin{array}{r}9 \\
8 \\
10\end{array}$ & $\begin{array}{l}1 \\
1 \\
1\end{array}$ & $\begin{array}{l}1 \\
1 \\
2\end{array}$ & $\begin{array}{l}2 \\
2 \\
2\end{array}$ & $\begin{array}{l}4 \\
4 \\
4\end{array}$ & $\begin{array}{l}0 \\
0 \\
0\end{array}$ & $\begin{array}{l}0 \\
0 \\
0\end{array}$ \\
\hline $\begin{array}{l}\text { Population exposure } \\
\left(10^{4} \text { man-reins) }\right.\end{array}$ & 1.54 & 0 & 1. & 8 & 23 & 1 & 3 & 3 & 5 & 0 & 0 \\
\hline \multicolumn{12}{|c|}{ Trajectory - 2000 } \\
\hline $\begin{array}{ll}\text { Particulates } & \left(10^{6} \mathrm{~T}\right) \text {. } \\
\text { Nitrogen oxides } & \left(10^{6} \mathrm{~T}\right) \\
\text { Sulfur dioxide } & \left(10^{6} \mathrm{~T}\right) \\
\text { Hydrocarbons } & \left(10^{5} \mathrm{~T}\right) \\
\text { Carbon monoxide } & \left(10^{6} \mathrm{~T}\right) \\
\text { Carbnn dioxide } & \left(10^{9} \mathrm{~T}\right)\end{array}$ & $\begin{array}{l}7.12 \\
3.66 \\
1.79 \\
9.32 \\
4.09 \\
1.13\end{array}$ & $\begin{array}{l}0 \\
0 \\
1 \\
0 \\
0 \\
0\end{array}$ & $\begin{array}{l}2 \\
2 \\
3 \\
1 \\
0 \\
4\end{array}$ & $\begin{array}{r}2 \\
-4 \\
8 \\
2 \\
1 \\
0\end{array}$ & $\begin{array}{r}4 \\
-9 \\
17 \\
4 \\
1 \\
-1\end{array}$ & $\begin{array}{l}1 \\
1 \\
2 \\
0 \\
2 \\
2\end{array}$ & $\begin{array}{l}3 \\
3 \\
3 \\
1 \\
2 \\
4\end{array}$ & $\begin{array}{l}0 \\
1 \\
1 \\
0 \\
2 \\
1\end{array}$ & $\begin{array}{l}1 \\
2 \\
3 \\
0 \\
7 \\
3\end{array}$ & $\begin{array}{l}0 \\
0 \\
1 \\
1 \\
0 \\
0\end{array}$ & $\begin{array}{l}0 \\
0 \\
1 \\
1 \\
0 \\
0\end{array}$ \\
\hline Sol id waste & 8.93 & 0 & 1 & 2. & 3 & 1 & 1 & 2 & 6 & 0 & 0 \\
\hline$\left(10^{6}\right.$ acres $)$ & 3.78 & 0 & 8 & 6 & 13 & 1 & 2 & 2 & 5 & 0 & 0 \\
\hline $\begin{array}{l}\text { Occupational } \\
\text { heal th \& safety } \\
\left.\text { Ded lhs (10 } 10^{1} \text { persons }\right) \\
\text { Injuries }\left(10^{3} \text { persons }\right) \\
\text { Man-days lost }\left(10^{5}\right)\end{array}$ & $\begin{array}{l}5.51 \\
6.93 \\
1.66\end{array}$ & $\begin{array}{l}0 \\
0 \\
0\end{array}$ & $\begin{array}{l}1 \\
1 \\
1\end{array}$ & $\begin{array}{l}1 \\
4 \\
5\end{array}$ & $\begin{array}{r}9 \\
9 \\
12\end{array}$ & $\begin{array}{l}0 \\
0 \\
1\end{array}$ & $\begin{array}{l}1 \\
1 \\
1\end{array}$ & $\begin{array}{l}3 \\
3 \\
2\end{array}$ & $\begin{array}{l}6 \\
6 \\
5\end{array}$ & $\begin{array}{l}0 \\
0 \\
0\end{array}$ & $\begin{array}{l}0 \\
0 \\
1\end{array}$ \\
\hline $\begin{array}{l}\text { Population exposure } \\
\text { (104 man-rems) }\end{array}$ & 5.82 & 0 & 0 & 10 & 22 & 0 & 1 & 2 & 6 & 0 & 0 \\
\hline
\end{tabular}




\begin{tabular}{|c|c|c|c|c|c|c|c|c|c|c|c|}
\hline \multicolumn{12}{|c|}{$\begin{array}{l}\text { Trajectory of Environmenta) Residual Estinates } \\
\text { (Percent Reduction from Base; Minus Sign Indicates Increase }\end{array}$} \\
\hline \multicolumn{12}{|c|}{ Pacific Region } \\
\hline & & Dist. & heat. & Ind. & cogen. & Retr & ofit & Rate & reform & h. re & design \\
\hline Pollutants & $\begin{array}{l}\text { Base } \\
\text { case }\end{array}$ & $\overline{\text { Low }}$ & $\overline{\text { High }}$ & Low & High & Low & High & $\overline{\text { Low }}$ & High & Low & High \\
\hline \multicolumn{12}{|c|}{ Trajectory - 1985} \\
\hline $\begin{array}{ll}\text { Particulates } & \left(10^{5} \mathrm{~T}\right) \\
\text { Nitrogen oxides } & \left(10^{6} \mathrm{~T}\right) \\
\text { Sulfur dioxide } & \left(10^{6} \mathrm{~T}\right) \\
\text { Hydrocarbons } & \left(10^{5} \mathrm{~T}\right) \\
\text { Carbon monoxide }\left(10^{6} \mathrm{~T}\right) \\
\text { Carbon dioxide }\left(10^{9} \mathrm{~T}\right)\end{array}$ & $\begin{array}{l}4.43 \\
2.23 \\
0.55 \\
7.67 \\
2.38 \\
0.57\end{array}$ & $\begin{array}{l}0 \\
0 \\
0 \\
0 \\
0 \\
0\end{array}$ & $\begin{array}{l}0 \\
1 \\
2 \\
0 \\
0 \\
1\end{array}$ & $\begin{array}{r}0 \\
-2 \\
2 \\
0 \\
<-1 \\
1\end{array}$ & $\begin{array}{r}0 \\
-2 \\
4 \\
<1 \\
-2 \\
7\end{array}$ & $\begin{array}{r}0 \\
1 \\
2 \\
<1 \\
0 \\
1\end{array}$ & $\begin{array}{r}0 \\
2 \\
4 \\
<1 \\
0 \\
0 \\
-3\end{array}$ & $\begin{array}{r}0 \\
1 \\
2 \\
<1 \\
0 \\
1\end{array}$ & $\begin{array}{r}2 \\
7 \\
11 \\
2 \\
1 \\
8\end{array}$ & $\begin{array}{l}0 \\
0 \\
2 \\
1 \\
0 \\
0\end{array}$ & $\begin{array}{l}0 \\
0 \\
2 \\
1 \\
0 \\
0\end{array}$ \\
\hline Solid waste & 0.66 & 0 & 6 & -11 & -32 & 3 & 6 & 4 & 35 & 0 & 0 \\
\hline (106 acres) & 7.52 & 0 & 0 & 1 & 4 & 0 & $<1$ & $<1$ & 3 & 0 & 0 \\
\hline $\begin{array}{l}\text { Occupational } \\
\text { health \& safety } \\
\text { Deaths (10 persons) } \\
\text { Injuries }\left(10^{3} \text { persons) }\right. \\
\text { Man-days lost }\left(10^{5}\right)\end{array}$ & $\begin{array}{l}9.90 \\
0.88 \\
0.39\end{array}$ & $\begin{array}{l}0 \\
0 \\
0\end{array}$ & $\begin{array}{l}2 \\
3 \\
0\end{array}$ & $\begin{array}{l}3 \\
6 \\
3\end{array}$ & $\begin{array}{l}12 \\
17 \\
13\end{array}$ & $\begin{array}{l}1 \\
2 \\
3\end{array}$ & $\begin{array}{l}3 \\
3 \\
3\end{array}$ & $\begin{array}{l}2 \\
2 \\
3\end{array}$ & $\begin{array}{l}14 \\
17 \\
15\end{array}$ & $\begin{array}{l}0 \\
0 \\
0\end{array}$ & $\begin{array}{l}0 \\
0 \\
0\end{array}$ \\
\hline $\begin{array}{l}\text { Population exposure } \\
\left.\text { (10 } 10^{4} \text { man-rems }\right)\end{array}$ & 0.45 & 0 & 0 & 16 & 47 & 2 & 7 & 4 & 42 & 0 & 0 \\
\hline \multicolumn{12}{|c|}{ Trajectory - 2000} \\
\hline $\begin{array}{lll}\text { Air Pollutants } & \\
\text { Particulates } & \left(10^{6} \mathrm{~T}\right) \\
\text { Nitrogen oxides } & \left(10^{6} \mathrm{~T}\right) \\
\text { Sul fur dioxide } & \left(10^{6} \mathrm{~T}\right) \\
\text { Hydrocarbons } & \left(10^{5} \mathrm{~T}\right) \\
\text { Carbon monoxide } & \left(10^{6} \mathrm{~T}\right) \\
\text { Carbon dioxide } & \left(10^{9} \mathrm{~T}\right)\end{array}$ & $\begin{array}{c}7.11 \\
2.88 \\
0.92 \\
12.4 \\
2.70 \\
0.76\end{array}$ & $\begin{array}{l}0 \\
0 \\
0 \\
0 \\
0 \\
0\end{array}$ & $\begin{array}{l}0 \\
1 \\
2 \\
1 \\
3 \\
1\end{array}$ & $\begin{array}{r}0 \\
-3 \\
2 \\
0 \\
2 \\
2\end{array}$ & $\begin{array}{r}1 \\
-6 \\
5 \\
0 \\
1 \\
3\end{array}$ & $\begin{array}{l}0 \\
1 \\
1 \\
1 \\
3 \\
1\end{array}$ & $\begin{array}{l}1 \\
1 \\
2 \\
1 \\
3 \\
2\end{array}$ & $\begin{array}{l}0 \\
1 \\
2 \\
1 \\
2 \\
1\end{array}$ & $\begin{array}{l}1 \\
3 \\
5 \\
2 \\
2 \\
3\end{array}$ & $\begin{array}{l}0 \\
0 \\
2 \\
2 \\
0 \\
0\end{array}$ & $\begin{array}{l}0 \\
0 \\
2 \\
2 \\
0 \\
0\end{array}$ \\
\hline Solid waste & 2.04 & 0 & 4 & -2 & -4 & 2 & 3 & 5 & 15 & 0 & 0 \\
\hline (10 $10^{6}$ acres) & 8.22 & 0 & 1 & 2 & 4 & $<1$ & 1 & 0 & 2 & 0 & 0 \\
\hline $\begin{array}{l}\text { Occupational } \\
\text { heal th \& safety } \\
\text { Deaths (10 } 10 \text { persons) } \\
\text { Injuries }\left(10^{3} \text { persons }\right) \\
\text { Man-days lost }\left(10^{5}\right)\end{array}$ & $\begin{array}{l}1.37 \\
1.45 \\
0.65\end{array}$ & $\begin{array}{l}0 \\
0 \\
0\end{array}$ & $\begin{array}{l}2 \\
3 \\
2\end{array}$ & $\begin{array}{l}5 \\
8 \\
8\end{array}$ & $\begin{array}{l}12 \\
18 \\
15\end{array}$ & $\begin{array}{r}2 \\
1 \\
2\end{array}$ & $\begin{array}{l}2 \\
3 \\
3\end{array}$ & $\begin{array}{l}3 \\
3 \\
5\end{array}$ & $\begin{array}{r}8 \\
8 \\
11\end{array}$ & $\begin{array}{l}0 \\
0 \\
0\end{array}$ & $\begin{array}{l}0 \\
0 \\
0\end{array}$ \\
\hline $\begin{array}{l}\text { Population exposure } \\
\text { (104 man-reins) }\end{array}$ & 2.37 & 0 & 0 & 15 & 33 & 2 & 4 & 6 & 16 & 0 & 0 \\
\hline
\end{tabular}


other risks are ignored here. If dependence on nuclear power did not increase, differences between emission estimates for 1985 and for 2000 would be more pronounced.

Table 13 shows estimates of each sector's relative contribution to each pollutant evaluated for both 1985 base cases (relative contributions for 2000 are similar). Note the dominant contributions of the transportation and supply sectors to certain air pollutants. Solid waste, land use, and health and safety emission coefficients are available in the MEERA-1 data base only for supply sector processes; hence the 100\% attribution. Obviously, other sectors may directly affect each of these impact measures, but unfortunately data are not available.

Varying energy demands in any single sector have impacts on overall emission estimates within the region which may be significant (e.g., transportation sector impacts on air pollutants) or insignificant (e.g., residential/ commercial sector impacts on land use or solid waste production). In reviewing the data discussed below, it should be recognized that each perturbation affects only a selected set of processes and activities; the effect on regional emissions production estimates may thus vary according to the mix of process affected.

\subsubsection{Trajectory Estimates}

Tables 11 and 12 also summarize the change in residuals estimates for each of the trajectories evaluated. The benefits of the conservation alternatives. are generally marginal in the low case estimates and only slightly better in the high case estimates. As intuitively expected, most technologies tend to decrease overall environmental residuals production. The reductions are roughly proportional to the amounts of energy saved for all conservation alternatives except industrial cogeneration and vehicle redesign.

Comparison of the conservation measures shows that rate reform affects only supply technology emissions, principally those from central station electricity generating plants. Retrofit reduces both supply and end-use emissions. Similar benefits arc expected from district heating, though the siludtion is complicated by the shift in fuel type and emission characteristics expected. Industrial cogeneration, because of the complex fuel shifting involved, produces mainly benefits in the Middle Atlantic region but increases in some pollutants in the Pacific region. Its benefits are related to the 


\begin{tabular}{|c|c|c|c|c|}
\hline \multicolumn{5}{|c|}{ Table 13} \\
\hline \multicolumn{5}{|c|}{$\begin{array}{l}\text { Base Case Environmental Impacts } \\
\text { Sector Contributions (Percent) }\end{array}$} \\
\hline 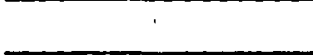 & Supply & Residential/comm & Industrial & Transportation \\
\hline \multicolumn{5}{|c|}{ Middle Atlantic - 1985} \\
\hline Particulates & 19 & 20 & 8 & 52 \\
\hline Nitrogen oxides & 45 & 10 & 4 & 41 \\
\hline Sulfur oxides & 52 & 18 & 19 & 10 \\
\hline Hydrocarbon & 16 & 4 & 8 & 72 \\
\hline Carbon monoxide & 2 & 2 & 54 & 42 \\
\hline Carbon dioxide & 35 & 27 & 12 & 26 \\
\hline Solid waste & 100 & a & a & a \\
\hline Land use & 100 & a & a & a \\
\hline Occupational & & & & \\
\hline health \& safety & 100 & a & a & a \\
\hline \multicolumn{5}{|c|}{ Pacific - 1985} \\
\hline Particulates. & 10 & 4 & 15 & 70 \\
\hline Nitrogen oxides & 34 & 3 & 5 & 58 \\
\hline Sulfur oxides & 47 & 5 & 22 & 27 \\
\hline Hydrocarbon & 24 & 1 & 1 & 74 \\
\hline Carbon monoxide & 1 & 1 & 18 & 81 \\
\hline Carbon dioxide & 19 & 14 & 23 & 44 \\
\hline Solid waste & 100 & a & a & $\mathbf{a}$ \\
\hline Land use. & 100 & a & a & a \\
\hline Occupational & & & & \\
\hline health \& safety & 100 & a & a & a \\
\hline
\end{tabular}

overall increase in efficiency of energy use and concomitant decrease in residuals production, but selected emissions (e.g., nitrogen oxides) increase because of the greater use of natural gas in the Middle Atlantic region and of industrial wastes and oil in the Pacific region (see below). With vehicle redesign, the projected reduction in gasoline usage decreases emissions only in the supply sector, i.e., in the refining of crude oils, and does not affect end-use, emissions from automobiles. Beacuse the emissions standards for light-duty vehicles (private cars) are related, not to fuel economy standards, but to vehicle-miles traveled (VMT), the only way to decrease auto emissions is to decrease VMT. In the base and low case estimates, VMT is assumed to remain constant and emission do not change significantly; in the high case estimates, auto emissions increase slightly because of projected increases in VMT. Vehicle redesign is thus unique in that it saves energy but has virtually no effect upon estimated emissions. 


\subsection{ENERGY AND ENVIRONMENTAL END-USE IMPACTS}

The regional perspectives presented in the previous section are of limited interest because the large mix of activities included within the RRES tend to mask the effects any single activity can produce on this system. This does not mean that significant energy or environmental impacts are not occurring. On the contrary, at the point of end use, the opposite may hold true. As discussed below, both district heating and industrial cogeneration may produce reductions in regional emissions, but sometimes at a significant cost to the local environment. District heating, for example, reduces residential/commercial end-use emissions, but at an environmental cost created by the district heating plant. In these analyses, it is assumed that the district heating plant burns coal. Coal combustion produces larger quantities of pollutants than the end-use applications replaced and thus increases local emissions burdens. In industrial cogeneration, an energy penalty is incurred in producing both electricity and process heat because, to deliver an equivalent amount of process heat, the industry must burn additional quantities of fuel, and fuel substitutions can al so occur. Each of these changes can affect 1ncal, and in some cases regional, environmental conditions.

Tables 14 to 17 present estimates of the changes in energy use requirements and emissions produced by each of these purturbations for district heating and industrial cogeneration. They include energy and emissions data not only for the end-use device (e.g.,residential furnace) but al so for the cogenerating plant. District heating plants cause slight increases in end-use energy demands and significant increases in environmental ellisstons. Sulfur oxides and nitrogen oxides emissions, for example, increase 100\% from the base

case. Land use and solid waste production al so increase. Thus, operation of a district heating plant produces a utility credit but, as the data suggest, at an end-use cost. Since utilities may be located hundreds of miles from demand centers, versus tens of miles. for district heating plants, the local impact may be of significant concern.

Industrial rogeneration involvos similar trade uffs. Because of the energy penalty incurred in coproducing electricity with process heat, industries cogenerating must consume larger amounts of energy. Fuel switching al so occurs. These variables interact to produce various impacts. In general, the environmental costs at the sites of fuel combustion appear to be significant. 


\section{Table 14}

District Heating End-Use Impacts - Middle Atlantic (Percent Reduction from Base; Minus Sign Indicates Increase)

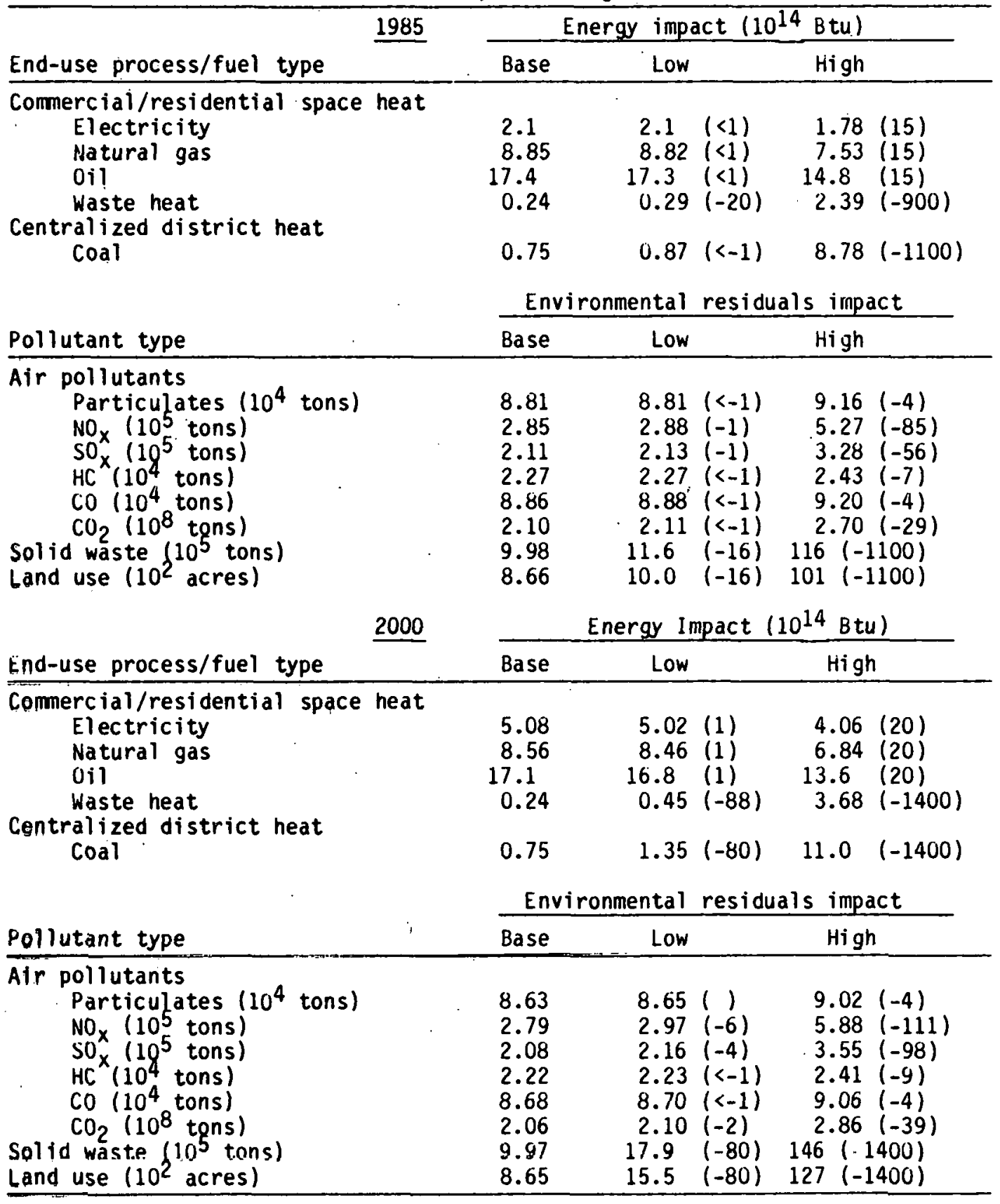




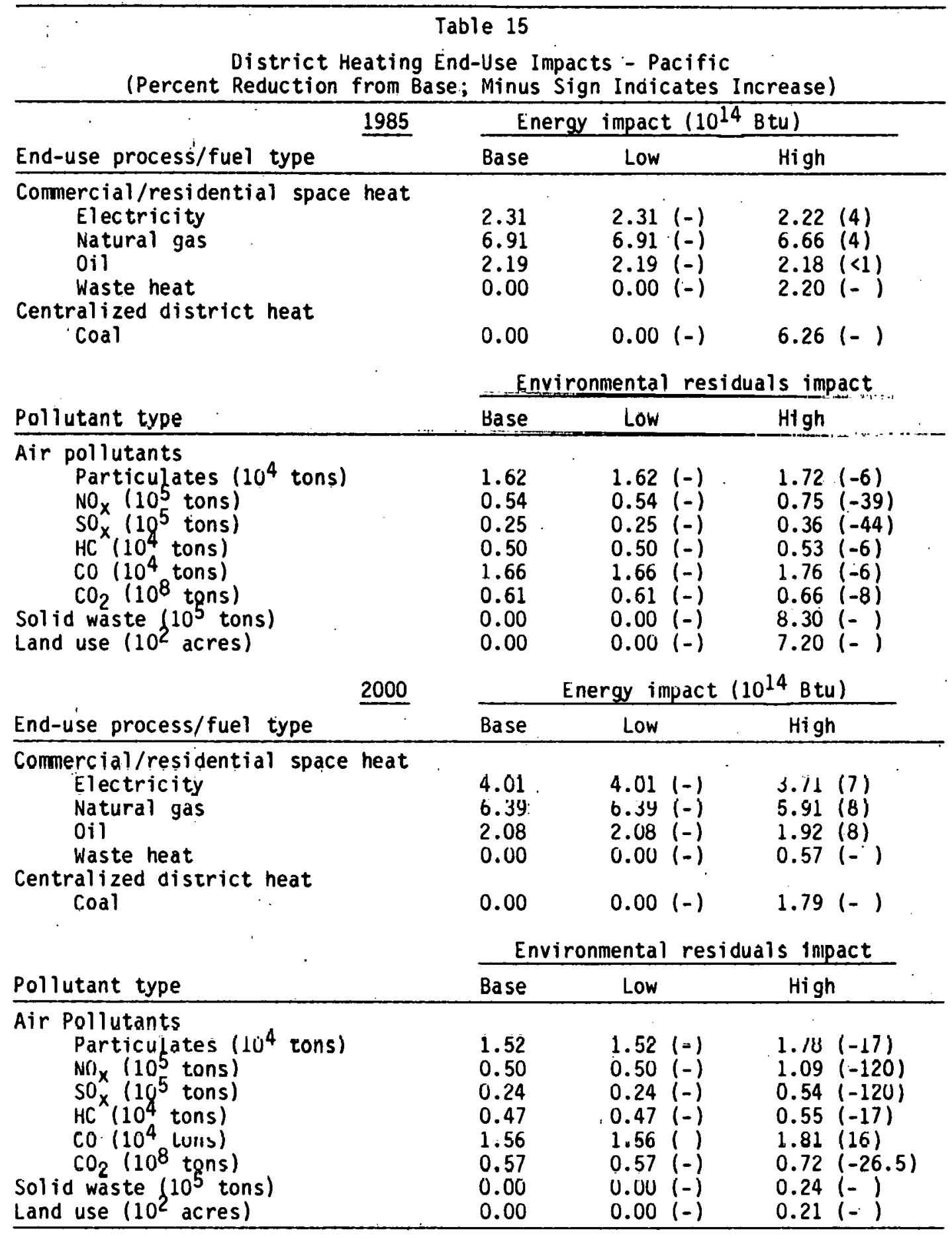




\section{Table 16}

Industrial Cogeneration End-Use Impacts - Middle Atlantic (Percent of Reduction from Base; Minus Sign Indicates Increase)

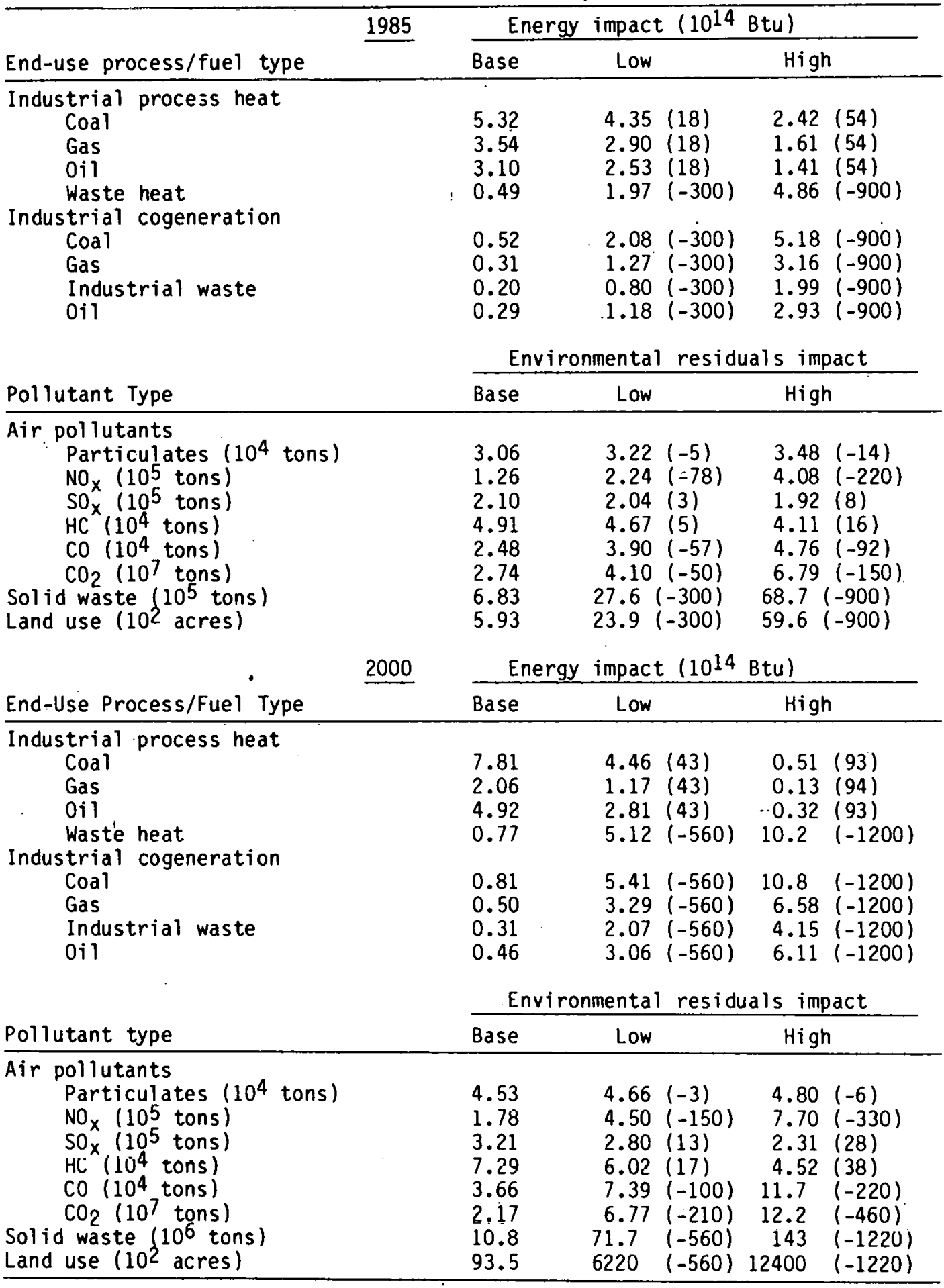




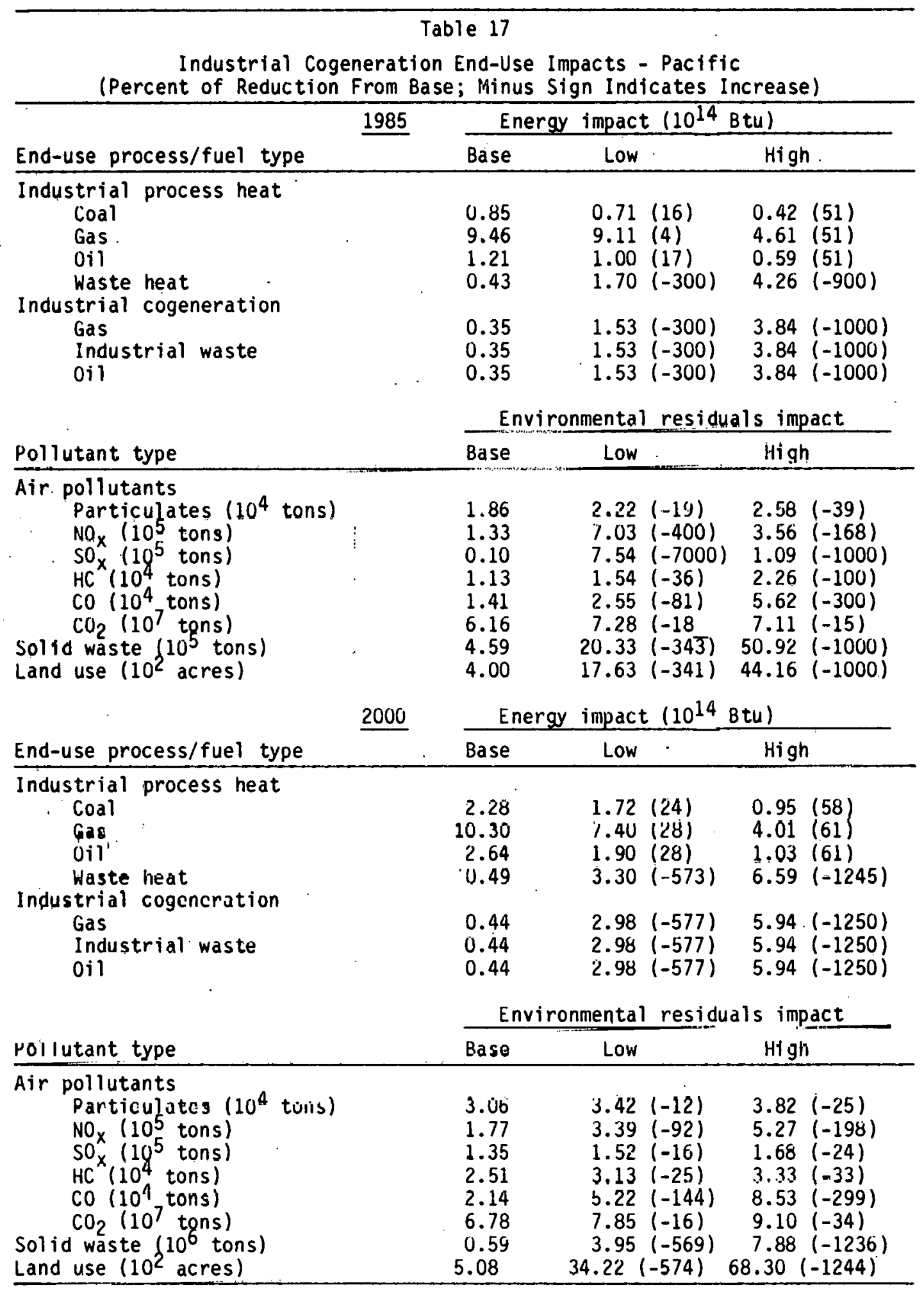


Retrofit reduces end-use energy consumption with similar impacts on enduse emission; it also provides credits throughout the rest of the system, but relatively insignificant ones. Rate reform reduces end-use electricity consumption but has no effect on end-use emissions; it reduces only supply technology emissions. Vehicle redesign, as discussed above, reduces end-use energy demand but does not reduce emissions: All these changes may be important at the local level, even though only marginal regional benefits are expected. 
5 REGIONAL COMPARISONS

Comparisons among the base trajectories for the two regions show that end-use demands are qualitatively similar le.g., the automobile is a major consumer of 011 ; most space heat is obtained from the combustion of natural gas and oil), but quantitative differences are seen in overall demands. More interesting regional differences appear generally in the supply sector and more specifically in the fuels used for electricity generation.

Overall energy. demands are greater in the Middle Atlantic region than those in the Pacific region in both years. Higher demand means higher supply requirements and greater production of environmental residuals. Thus, regional emission estimates for the Middle Atlantic regiun exceed those for the Pacific region. The differences are exaggerated by the greater dependence on fossil fuels in the Middle Átlantic regions; technologies using tossil fuel are inherently more polluting than those using hydroelectric and nuclear power, which are more fully utilized in the Pacific region. Because of these differences, equivalent reductions in overall supply requirements will tend to produce greater benefits in the Middle Atlantic than in the Pacific region. Conservation strategies such as rate reform or retrofit could induce such changes.

Other conservation alternatives, such as industrial cogeneration, can result in changes in the regional mix of fuels used in electricity generation, which can have far-reaching environmental consequences. In the Middle Atlantic region electricity is produced primarily from coal and nuclear fuel and in the Pacific region mainly from hydropower, natural gas, and nuclear fuel. Industrial cogeneration could decrease the use of most of these fuels at the point of central station electricity production but at an energy cost incurred at the point of cogeneration. The consequences of substitutions vary according to the fuel mix. In the Middle Atlantic region, exchanges between coal, oil, and natural gas are not likely to produce significant changes in overall environmental quality because these are all relatively "dirty" fuels, but adverse effects are expected in the Pacific region because "clean" fuels are being replaced by "dirty" fuels. In both regions, industrial cogeneration could increase dependence on $0 i 1$ and natural gas and independence from nuclear energy and coal. The conclusions are obviously based on a large number of assumptions but are nevertheless plausible and should receive careful consideration. 


\section{DISCUSSION}

\subsection{METHODOLOGY}

The modeling effort described is a useful methodology for quantitative assessment of the energy and environmental impacts of different energy futures. The model, however, serves only as an accounting tool. Changing any set of assumptions can change both the energy and the environmental emission estimates produced. Several features of this analysis should be emphasized because of their significant effects on all the variables.

All utility credits are assumed to be equally apportioned among all fuels in central station electricity generation according to the allocations in the base case, except for hydroelectricity capacity, which is always kept constant at its base case value. In actuality, economic dispatch methods employed by many power pools might not allocate reduction in the utility network in this manner. Changing the allocations for electricity generation can have pronounced effects on emissions and on energy use by fuel type. For industrial cogeneration, for example, the analysis suggests that electricity generating capacity using nuclear, natural gas, and coal would accrue the greatest benefits, in absolute terms, from reductions in the utility supply network, whereas, in actuality, economic dispatch might suggest that the credit be provided to oil-fired plants. In the residential/commercial sector it is again assumed that fuel savings benefits achieved via retrofit are apportioned according to the mix of fuels used in the base cases. In actuality, electrically heated homes are generally more energy efficient and thus less affected by retrofit, so that this benefit might more properly be assigned to oil and gas. In the transportation sector, it is assumed that emissions and fuel economy are not directly related; thus, significant savings in energy are noted but little benefit to the environment. Finally, the overall energy savings potentials are merely educated guesses and could vary considerably depending on economics and incentives credited. These estimates are therefore merely a guide.

\subsection{RESULTS}

The results of the quantitative analyses suggest that each of the conservation technologies considered is likely to produce regional environmental benefits. Narrow analysis of emission estimates alone may, however, provide incomplete or incorrect perspectives because relevant regulatory and meteorological phenomena are ignored. 
Vehicle redesign, for example, is likely to decrease oil use significantly but may produce only marginal reductions in environmental emissions. Since federal standards for light-duty vehicles link emissions to vehicle-miles traveled 23 rather than to EPCA fuel economy standards, improvements in fuel economy will not directly produce improvements in environmental quality. Because transportation sector pollutants play a major role in regional air quality, alternative strategies aimed at minimizing VMT rather than increasing fuel economy may prove to be more environmentally beneficial and should be more fully explored.

Several interesting issues are associated with district heating technologies. District heating is likely to increase local emission burdens even though area source emissions will decline, but, because of differences in meteorological dispersion characteristics, local air quality may be improved. District heating plants, in contrast to residential/commercial furnaces, will need to comply with various federal, state, and local emission control requirements. A minimum stack height standard may be required; variations in stack height can significantly affect dispersion and exposure patterns. In general, use of a tall stack is likely to improve local air quality (even though end-use emission burdens increase) but increase long-range transportation potentials. Depending on population densities, mean weighted exposures could either increase or decrease. 24 Detailed studies of control requirements, meteorological dispersion patterns, and demographics must be evaluated to assure that application of this technology will not create adverse air quality and health effects.

Application of the district heating concept may also have important effects on future power plant siting options. At present the Clean Air Act lends to encouráge new power plant construction at sites remote from population centers. District heating plants, in constrast, must be located in close proximity to their potential customers. An interesting dichotomy, thus exists. If emission trade offs are permitted, the Clean Air Act may encourage local rather than remote siting. These issues need to be explored.

Industrial cogeneration can have far-reaching effects by altering future energy use patterns in specific regions. Since this may affect not only fuel options but also the environment, the potential long-term consequences of this technology need to be evaluated. Increased use of industrial cogeneration affects future siting options by shifting electricity production from large 
central station plants to smaller decentralized facilities. Associated with the shift in location is the concomitant potential for changing overall control strategies, subsequent residuals production, and exposure patterns. These smaller facilities may be located closer to population centers and would probably emit larger quantities of pollutants per Btu consumed.25-27. The plants may also be more difficult to police by regulatory agencies.28 Each of these issues deserves careful consideration.

Retrofit and rate reform avoid most of the complications imposed by the other technologies reviewed.

The benefits of each alternative are expected to be fairly modest, but each has been reviewed only independently. The combined benefits of all. these alternatives accumulated over a large number of years may be quite significant. 


\section{REFERENCES}

1. P. D. Moskowitz, T. Q. Le, and B. Pierce, "Ranking Energy Conservation Measures to Establish Research Priorities: Synopsis of a Workshop," BNL 51046 (1979), Brookhaven National Laboratory, Upton, NY.

2. A. L. Hermelee, "Regional Reference Energy Systems," ERRI EA-462 (1977), prepared for the Electric Power Research Institute, Palo Alto, CA.

3. W. A. Sevian, "The Energy System Network Simulator (ESNS): General Description and Sample Analysis" BNL 50753 (1975), Brookhaven National Laboratory, Upton, NY.

4. W. A. Sevian, "Models for Energy-Environmental Residuals Analysis," In Preparation (1979), Brookhaven National Laboratory, Upton, NY.

5. "Environmental Impacts, Efficiency, and Cost of Energy Supply and EndUse," Hittman Assnciates, Inc., Columbia, MD (1974).

6. W. A. Sevian and P. D. Moskowitz, "Energy System Network Simulator: Databook," (1978), Brookhaven National Laboratory, Upton, NY.

7. J. Karkheck, E. Beardsworth, and J. Powell, "Technical and Economic Aspects of Potential U.S. District Heating Systems," BNL-21287 (1976), Brookhaven National Laboratory, Upton, NY.

8. M. Jones, "Energy Supply and Demand in the New York City Region," BNL-19493 (1974), Brookhaven National Laboratory, Upton, NY.

9. "Cogeneration: Technical Concepts, Trends and Prospects," Department of Energy, FFU-1703, Washington, DC, (1978).

10. P. M. Meier, "Long-Range Regional Power Plant Siting Model," J. Energy Div., ASCE 105(EY1), Proc. Paper 14322 (1979).

11. Edison Electric Institute Statistical Yearbook: Historical Series, Edison Electric Institute, New York, NY (1975).

12. "The Potential for Cogeneration Development in Six Major Industries by 1985," Reșoụrce Pḷanning Associates, Washington, DC. (1977).

13. S. Kaplan, "Energy Use and Distribution in the Pulp, Paper and Boardmaking Industries," ORNL/TM-5884 (1977), Oak Ridge National Laboratory, Oak Ridge, TN.

14. Environmental Quality - The Ninth Annual Report, Council on Environmental Quality, Washington; DC (19ा8).

15. "The National Program for Building Thermal Envelope Systems and Insulating Materials," Department of Energy, ICS-0059, Washington, DC, (1979).

16. M. Tyson, "Residential Heat Load Calculations for the Northeast," Draft Report (1979), Brookhaven National Laboratory, Upton, NY. 
17. W. S. Chern, "Regional Econometric Model, for Forecasting Electricity Demand by Sector and by State," ORNL/NUREG-99 (1978), Oak Ridge National Laboratory, Oak Ridge, TN.

18. "Fact Sheet, Automobile Fuel Economy," Environmental Protection Agency Office of Air and Waste Management, Washington, DC, 1978.

19. New York Times, Aug. 2, 1979.

20. "Project Independence Report," Federal Energy Administration, Washington, DC (1974).

21. "Transportation Energy Conservation Data Book: Edition 2," ORNL 5320 (1978), Oak Ridge National Laboratory, Oak Ridge, TN.

22. "Potential for Energy Conservation in the United States: 1974-1978," National Petroleum Council, Washington, DC (1974).

23. "Mobile Source Emission Factors," EPA-400/9-78-006 (1978b), Environmental Protection Agency - Office of Transportation and Land Use Policy, Washington, DC.

24. R. E. Meyers, R. T. Cederwel1, and J. A. Storch, "Atmospheric Pollution from Fossil Fuel Energy: Risk Impact Analysis," Draft Report (1977), Brookhaven National Laboratory, Upton, NY.

25. "State Implementation Plans Emission Regulations for Particulate Matter: Fuel Combustion," EPA-4582-76-010 (1976), Environmental Protection Agency

- Office of Air and Waste Management, Washington, DC.

26. "State Implementation Plan Emission Regulations for Sulfur Oxides: Fuel Combustion," EPA-450/2-76-0029 (1977a), Environmental Protection Agency Office of Air and Waste Management, Washington, DC.

27. "Compilation of Air Pollutant Emission Factors Third Edition, Including Supplements 1-7," AP-42 $\left(1977_{b}\right)$, Environmental Protection Agency, Research Triangle Park, NC.

28. C. F. Bryant and P. D. Moskowitz, "Energy Conservation in Two Northeastern Cities: Opportunities, Problems and Prospects, "Draft Report (1979), Brookhaven National Laboratory, Upton, NY.

29. E. Hirst and J. Carney, "Residential Energy. Use to the Year 2000: Conservation and Economics," ORNL/(CON-13) (1977). 
THIS PAGE

\section{WAS INTENTIONALLY}

LEFT BLANK 
APPENDIX A

CALCULATIONS OF DEMAND REDUCTION BY RETROFIT

$-45-$ 


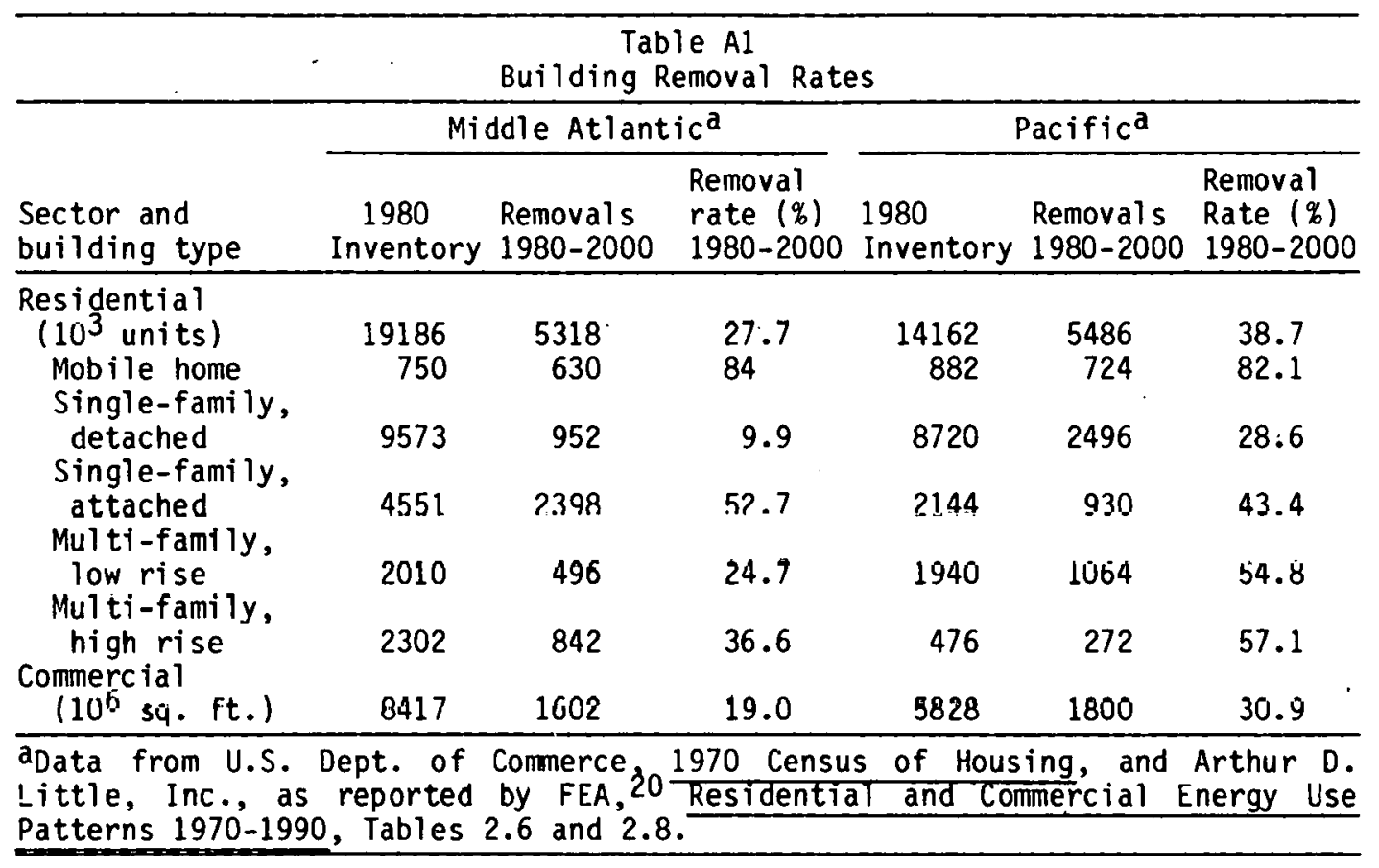

\begin{tabular}{|c|c|c|c|}
\hline \multirow[b]{3}{*}{ Region and housing type } & \multicolumn{3}{|c|}{$\begin{array}{l}\text { Table A2 } \\
\text { and Commercial Buildings ( } 10^{3} \text { units) }\end{array}$} \\
\hline & \multirow[b]{2}{*}{$\begin{array}{l}\text { Building } \\
\text { inventory, } 198013\end{array}$} & \multicolumn{2}{|c|}{$\begin{array}{l}\text { Retrofitted buildings } \\
\text { by } 2000^{\mathrm{a}}\end{array}$} \\
\hline & & $\begin{array}{l}\text { Low } \\
\text { case }\end{array}$ & $\begin{array}{l}\text { lli gli } \\
\text { case }\end{array}$ \\
\hline $\begin{array}{l}\text { Middle Atlantic } \\
\text { Mobile home } \\
\text { Single-family, detached } \\
\text { Single-family, attached } \\
\text { Multi-family, low rise } \\
\text { Multi-family, high rise } \\
\text { Commercial building (106 sq.ft.) }\end{array}$ & $\begin{array}{r}53 \overline{7} \\
6679 \\
3280 \\
1613 \\
1819 \\
5538\end{array}$ & $\begin{array}{r}60 \\
4212 \\
1086 \\
850 \\
808 \\
3140\end{array}$ & $\begin{array}{r}82 \\
5716 \\
1474 \\
1154 \\
1096 \\
4262\end{array}$ \\
\hline $\begin{array}{l}\text { Pacific } \\
\text { Mobile home } \\
\text { single-family, detached } \\
\text { Single-family, attached } \\
\text { Multi-family, low rise } \\
\text { Multi-family, high rise } \\
\text { Commercial building }\left(10^{6} \text { sy.rl. }\right)\end{array}$ & $\begin{array}{r}518 \\
6150 \\
1589 \\
985 \\
873 \\
3975\end{array}$ & $\begin{array}{r}65 \\
3074 \\
629 \\
312 \\
262 \\
1922\end{array}$ & $\begin{array}{r}88 \\
4172 \\
854 \\
423 \\
356 \\
2609\end{array}$ \\
\hline \multicolumn{4}{|c|}{$\begin{array}{l}\text { aderived by multiplying building inventory } 1980 \text { by } 0.95 \text { (high case) or } 0.70 \\
\text { (current trend), then by }(1-R) \text { where } R \text { is the removal rate } 1980-2000 \text {. }\end{array}$} \\
\hline
\end{tabular}


Table A3

Reduction in Unit Basic Energy Uernands in Space Heat Due to Retrofit

\begin{tabular}{|c|c|c|c|c|c|c|}
\hline \multirow[b]{3}{*}{ Sector and building type } & \multicolumn{3}{|c|}{ Middle Atlantic } & \multicolumn{3}{|c|}{ Pacific } \\
\hline & \multirow{2}{*}{$\begin{array}{l}\text { Unit basic } \\
\text { energy demand, } \\
\text { base case } 13\end{array}$} & \multicolumn{2}{|c|}{$\begin{array}{l}\text { Unit } \\
\text { reduction }\end{array}$} & \multirow{2}{*}{$\begin{array}{l}\text { Unit basic } \\
\text { energy demiand, } \\
\text { base case } 13\end{array}$} & \multicolumn{2}{|c|}{$\begin{array}{l}\text { Unit } \\
\text { reduction }\end{array}$} \\
\hline & & Low & High & & Low & High \\
\hline \multicolumn{7}{|l|}{$\begin{array}{r}\text { Residential buildings } \\
\left(10^{6} \mathrm{Btu} / \text { household }\right)\end{array}$} \\
\hline $\begin{array}{l}\text { Mobile home } \\
\text { Single-family, detached } \\
\text { single-fanily, attached } \\
\text { Multi-family, low rise } \\
\text { Multi-family, high rise }\end{array}$ & $\begin{array}{l}51.4 \\
73.6 \\
41.4 \\
26.5 \\
23.6\end{array}$ & $\begin{array}{r}10.3 \\
14.7 \\
8.3 \\
5.3 \\
4.7\end{array}$ & $\begin{array}{r}15.4 \\
22.1 \\
12.4 \\
8.0 \\
7.1\end{array}$ & $\begin{array}{l}25.2 \\
39.7 \\
26.0 \\
14.1 \\
12.5\end{array}$ & $\begin{array}{l}5.0 \\
7.9 \\
5.2 \\
2.8 \\
2.5\end{array}$ & $\begin{array}{r}7.6 \\
11.9 \\
7.8 \\
4.2 \\
3.8\end{array}$ \\
\hline $\begin{array}{c}\text { Commercial buildings } \\
\left(10^{3} \mathrm{Btu} / \mathrm{sq}: \mathrm{ft} .\right)\end{array}$ & 111.1 & 22.2 & 33.3 & 76.9 & 15.4 & 23.1 \\
\hline
\end{tabular}

a Assumed to be $20 \%$ of the base case.

bAssumed to be $30 \%$ of the base case.

Table A4

Air-Conditioning Inventory and Unit Energy Reduction

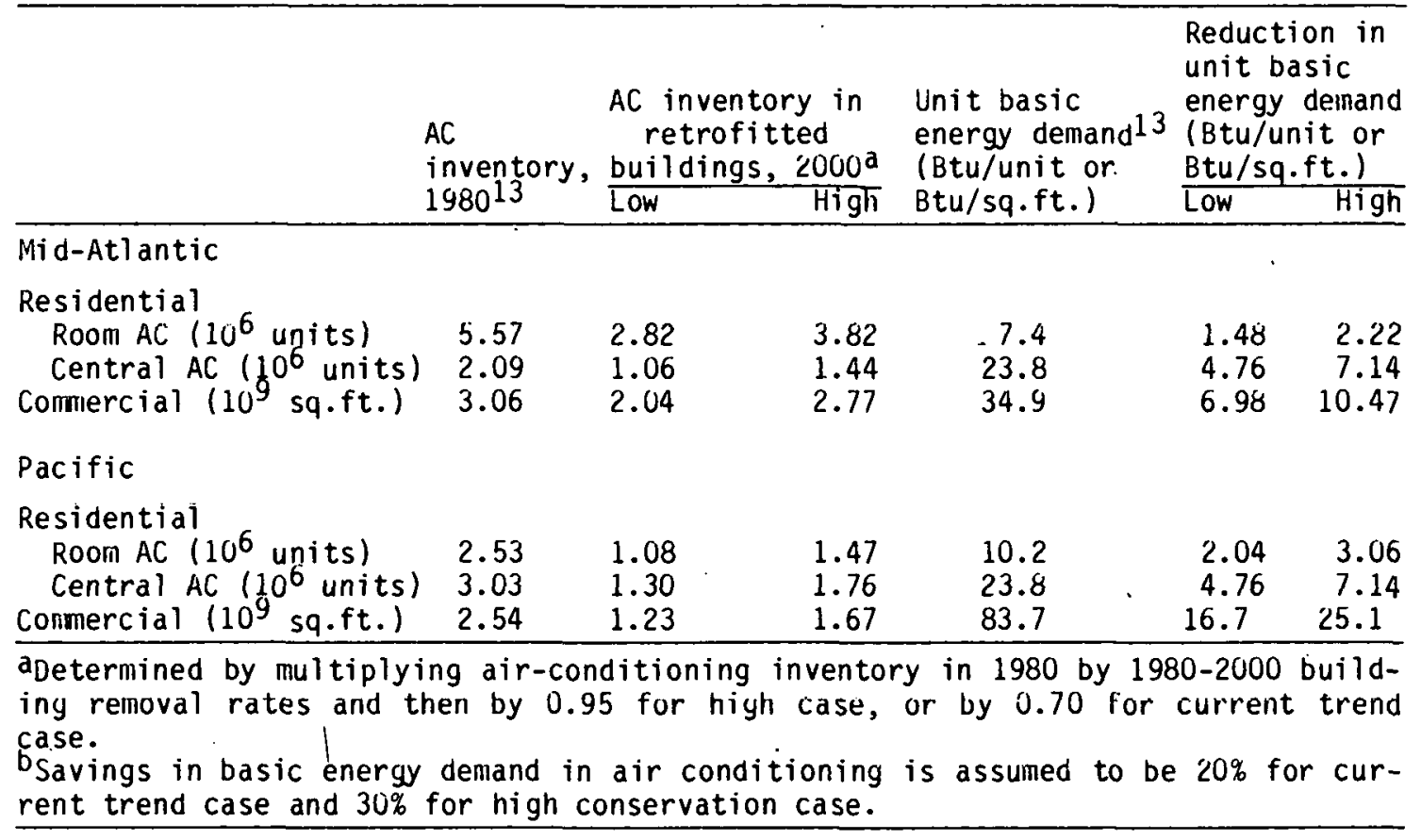




\section{THIS PAGE}

\section{WAS INTENTIONALLY \\ LEFT BLANK}


APPENDIX B

CALCULATIONS OF DEMAND REOUCTION BY RATE REFORM 
THIS PAGE

\section{WAS INTENTIONALLY \\ LEFT BLANK}


WORKING PAPER ON ESTIMATING THE CHANGE IN END-USE DEMAND FOR ELECTRICITY IN THE

REGIONAL REFERENCE ENERGY SYSTEM DUE TO THE IMPLEMENTATION OF UTILITY RATE REFORM AND LOAD MANAGEMENT

Ed Edelson

. July 2, 1979

Pacific Northwest Laboratory

Richland, Washington 99352 


\section{CONTENTS}

\subsection{OBJECTIVE}

2.0 PREVIOUS APPROACH ANO CRITIQUE

3.0 MODIFIED APPROACH

3.1 OVERVIEW

3.2 COVENTS AND CONCERN

\subsection{ANALYSIS}

3.3.1 Price [lasticities

3.3.2 Price Changes

3.3.3 Sector Demand Changes

4.0 CONCLUDING REMARKS

5.0 REFERENCES 


\subsection{OBJECTIVE}

The Regional Reference Energy System is being utilized in a study to show the impacts on energy consumption and environmental inpacts of various energy conservation measures. One of them is utility rate reform and load management. Application of these measures is expected to have two distinct types of effects:

1. Shift demand for electricity from peak use hours to off-peak hours in order to minimize the utilization of expensive peaking turines $(a)$ and maximize the use of cheaper base load plants.

2. Reduce consumption of electricity as customers see higher prices due to movements in electricity pricing away from average cost towards marginal or replacement cost.

The structure of the RES is not well suited to showing changes of the first type. The utilization of peaking turbines (oil and natural gas) in the model is so small that any change would be insignificant. This should not be interpreted as saying the benefits of "load levelingi" are insignificant but only that this model is not suited for showing such changes. (b)

The second effect can be shown by changing the consumption of electricity for the three sectors - residential, commercial and industrial. However, unlike the implementation of a more efficient technical device, the changes caused by utility rate reform are more subtle and diverse. For example, one effect of moving towards marginal price by an electric utility is that other energy sources - coal, natural gas, oil or others - might become more attractive. Although electrical consumption might decrease, consumption of other fuels might increase. Thus it becomes very difficult to isolate those changes on electric utility sector in the RES model without changing the utilization of other energy forms.

(a) The situation in the Pacific region is slightly different in that the cheapest energy source - hydropower - is used for peaking. Nevertheless, a more even load curve would allow hydro to substitute for more expensive base luad plarils.

(b) See PNL Memorandum to Pien Le from Ed Edelson on Utilizing ME ERA 1 (formerly ESIVS) To Simulate the Regional Response to Utility Rate Reform and Load Management, May 29, 1979. 
The objective here is to make a preliminary analysis of the changes in the electric utility industry while holding everything else in the model constant. "Lifestyle"(a) changes and the substitution of more efficient electrical devices are the only reactions to the price change that fit this narrow definition. Again this is not meant to be realistic but indicative of the type of change expected in the reference model. These changes will then be used to indicate the types of environmental changes attributable to such reductions in electricity consumption. Obviously the discussion above indicates a bias towards showing only the benefits of reduced electrical consumption without showing the concommitant increases in the use of other direct funds.

(a) For the industrial sector this might imply the use of labor for tasks previously accomplished by electricity. 


\subsection{PREVIOUS APPROACH AND CRITIQUE}

In response to the complexity of the impacts of moving towards the higher marginal cost of electricity as the price charged to consumers, projections of an econometric model developed by Oak Ridge National Laboratory were considered as applicable (Ref. 1). "The base case is that model was used to show the "low" impact of high prices and their high case was used to show the "high" impact of utility rate reform. Before discussing this approach, it is important to note that the RES only allows for minor changes in per capita electricity consumption. Looking at the Fuel Mix tables in Appendix B of Reference 2, the only end use categories showing a change in energy (not electricity) consumed per unit of analysis are aluminum and iron (See Table 1). In fact, as Table 1 also shows the RES projections include an increase in the share of electricity in all appropriate categories except for a very slight shift to methane for commercial air conditioning.

Because all econometric work on the demand for electricity shows a nonzero elasticity, such a projection implies no change in the real price of energy over the model's horizon (Ref. 1, 3, and 4). Thus the change in demand for electricity from the RES base when one incorporates price effects is quite striking (see Table 2). It should be noted that the projection given in RES is only meant as a reference and not as a forecast. The critique that price is not included is not meant to dispute the utility of the model but only to raise a caution flag in how it is used.

The Oak Ridge model had many desirable qualities. Its sector and regional breakdown are very similar to the RES structure. (ORNL did not have a transportation sector but electrical consumption is small in this sector. ORNL also does not include Alaska. Here again electrical consumption is very smal1.) The regional breakdown and the variations allowed for price elasticity by region is very useful because one of the major aspects of the research agenda is to look at regional differences.

But the ORNL projections did have some drawbacks. First it only looks to the year 1990. Figures for the year 2000 must be extrapolated. More important, 
TABLE 1. National Changes in Unit Basic Demand and $f_{j} f_{n}$ Electricity by Category

\begin{tabular}{|c|c|c|}
\hline Sector and Category & $\begin{array}{l}\text { Does Unit } \\
\text { Basic Demand } \\
\text { Change? } \\
\end{array}$ & $\begin{array}{c}\text { Does } f \text { for } \\
\text { Electricity } \\
\text { Change? }\end{array}$ \\
\hline \multicolumn{3}{|l|}{ Residential } \\
\hline Space lleat & No & Incredses \\
\hline Water Heat & No & Increases \\
\hline Air Conditioning & No & No \\
\hline Cooking & No & Increases \\
\hline Appl. \& Lighting & No & No \\
\hline Commercial & & \\
\hline Space Heat & No & Increases \\
\hline Water Heat & No & Increasẹs \\
\hline Cooking & No $(a)$ & Increases \\
\hline Air Conditioning & No & Decreases $(1 \%)$ \\
\hline Misc. Electric & No & No \\
\hline \multicolumn{3}{|l|}{ Industrial } \\
\hline Aluminum & Decreaces & No \\
\hline Iron & No & No . \\
\hline Steel & Increases & Inçreases \\
\hline Electric Drive & No & No \\
\hline
\end{tabular}

(a) As calculated from Basis and $E$. Source: Reference 2, Appendix B. 
TABLE 2. Comparison of RES and ORNL Electricity

Demand Projection ( $\left.\times 10^{9} \mathrm{kWh}\right)$

Region: Pacific

\begin{tabular}{|c|c|c|c|c|c|c|c|}
\hline Year & $\underline{R E S}^{(a)}$ & $\begin{array}{l}\text { ORNL } \\
\text { Base }\end{array}$ & $\begin{array}{l}q(b) \\
\text { Dif }\end{array}$ & $\begin{array}{l}\text { ORNL } \\
\text { LOW } \\
\end{array}$ & $\begin{array}{c}\% \\
\text { Dif }\end{array}$ & $\begin{array}{l}\text { ORNL } \\
\text { High }\end{array}$ & $\begin{array}{c}\% \\
\text { Dif } \\
\end{array}$ \\
\hline 1972 & 263.9 & & & & & & \\
\hline 1974 & 273.2 & 228.2 & -16.5 & 228.2 & -16.5 & 228.2 & -16.5 \\
\hline 1980 & 344.1 & 294.0 & -14.6 & 297.2 & $\therefore-13.6$ & 290.9 & -15.5 \\
\hline 1985 & 408.1 & 370.0 & -9.3 & 380.6 & -6.7 & 360.0 & -11.8 \\
\hline 1990 & 495.6 & 451.3 & -9. & 473.5 & -.4 .5 & 430.3 & -13.2 \\
\hline 2000 & 646.5 & 584 & -9.7 & 617.9 & -4.4 & 552.79 & $=15.5$ \\
\hline
\end{tabular}

Region: Middle Atlantic

$\begin{array}{llllllll}1972 & 241.5 & 171.1 & -29 & 169.95 & -30 & 172.6 & -29 \\ 1974 & 238.0 & 229.4 & -4 & 229.4 & -4 & 229.4 & -4 \\ 1980 & 373.0 & 291.1 & -22 & 291.7 & -22 & 290.3 & -22 \\ 1985 & 470.2 & 405.8 & -14 & 409.6 & -13 & 401.5 & -15 \\ 1990 & 674.8 & 523.9 & -22 & 520.0 & -22 & 517.6 & -23 \\ 2000 & 987.6 & 694 . & -30 & 102.6 & -29 & 683.78 & -31\end{array}$

(a) Heat rate $=10,47 \% \mathrm{BTU} / \mathrm{kWh}$

(b) The percentage difference between the ORNL case and RES 
the model's sophistication means that many other factors are analyzed in addition to price increases. For example, the cross-elasticities between electricity consumed and the price of natural gas is a very important element as are income effects. In addition other macroeconomic changes can occur shifting production and consumption between regions. Thus using the ORNL electrical consumption projection directly could be misleading in that it shows changes other than those due to customers seeing higher prices for electricity. It should be noted that the ORNL used average prices and not marginal prices. However, because these average prices are so much higher than those assumed in RES, it was felt that they were appropriate proxies for the implementation of marginal pricing.

Une quick alternative to using the ORNL projectious is lu slmply use the ratios between the ORNL low case demand (with real prices for electricity not changing after 1974) to the ORNL high case demand (with nominal prices for electricity increasing by about $5 \%$ per year). This ratio would then be applied to the RES base numbers. This approach al though straightforward does not really overcome the problems discussed above. One still finds ratios where the ORNL high case indicate increased consumption. (a) Intuitively and economically this is wrong when considering the assumptions that utility rate reform only changes the price of electricity and not any other energy forms.

(a) This is because the ORNL high case is driven by increasing prices of natural gas and oil. If these increase faster than electricity, then electricity might still look like a good deal. 


\subsection{MODIFIED APPROACH}

\subsection{OVERVIEW}

The problem for this analysis is to look at an existing engineering model and make changes to it that reflect economic or behavioral reactions to the implementation of marginal price for electricity. It is assumed that the nature of the engineering model implies that the real prices for electricity and other forms of energy are constant. Thus the implementation of utility rate reform under these assumptions implies that electricity consumers see a higher real price for electricity only and no other changes in their income or other prices. (a)

Very simply, the analysis involves the use of a price elasticity for electricity $(\varepsilon)$, a percentage change in electricity price as utility rate reform is implemented $(\triangle P)$, and the existing RES reference case electricity consumed $(E)$. Because price elasticity is defined as

$$
\frac{\Delta \% E}{\Delta \% P}=\varepsilon \quad, \text { where } \Delta \% E=\frac{\Delta E}{E(\text { original })} \text {. }
$$

then $\quad \Delta E=E(\Delta \% P) E$ (original)

where $\Delta E$ is the percentage change in electricity consumed.

The modified electricity consumed $=E \times(1-\Delta E)$.

This calculation is done for each region (Pacific and Middle Atlantic) and each sector (residential, commercial and industrial) for the years 1985 (short-. run elasticity) and 2000 (long-run elasticity) under a low $\Delta P$ and a high $\Delta P$ as sumption.

(a) The income assumption is probably the most unrealistic considering the nature of electric utilities and the rate of return regulation that constrains these profits. What to do with this "excess revenue" is an unresolved problem at this time and for simplicity it is ignored. 


\subsection{CAVENTS AND CONCERN}

As noted in the overview, the analysis requires several key inputs:

- price elasticities by region and sector

- percentage difference between marginal and average price by region and sector.

Price elasticity is very powerful concept central to the study of microeconomics. However, when it comes to electricity, the concept becomes extremely difficult to quantify in a theoretically plausible way. Taylor's survey provides an excellent review of many of the conceptual problems that face the study of , the demand for electricity. (3) These include the modeling of consumer bchavior in response to multistep block pricing and the utilization of the available average price data. Both of these are not typical of other gouds and surveys where the consumers usualiy faces one price regardless of quantity and that price is the marginal cost of production. As a result, Taylor's survey finds many contradictions between the result of several studies. As an example, Taylor cites the conclusion of one study by Fisher and Koysen:

"The states fall into two major groups, the first of which shows a near zero price elasticity and the second of which shows a much higher price elasticity although still less than one. The first group includes roughly the states east of the Rockies, north of the Mason-Dixon line, plus the "Border States", and Florida and California. The second group consists of the rest of the nation. This grouping is topologically reasonable and it corresponds to a basic economic difference: the states in the second group are in a broad sense economically "younger" than those in the first group. The implication... is thus that as the economic of all states mature, short-run houschold electricity demand will become even less price sensitive than it now is.

This sounds plausible and yet the ORNL model shows lower elasticities for the residential sector for the mountain and pacific state than the New England and Middle Atlantic.

Data on price elasticies below the sectoral level are available but not very comprehensive. As a result, only sector elasticities are used to calculate the electricity saved. The savings is then allocated over appropriate categories i.e., space heat but not process heat. These allocations are somewhat arbitrary al though hopefully good judgement was used. 
Finding regional data on the difference between marginal and average cost electricity is also problematic. In addition to finding such data (more will be provided on this problem) there is a conceptual problem of determining what is appropriate for this exercise. Should it be the marginal cost of producing electricity in 1972 since RES utilizes a 1972 reference base? Or should it be the percentage difference in the year assumed for implementing RES? Needless to say the assumptions used here were not totally satisfactory.

\subsection{ANALYSIS}

The generalized formula for calculating the amount of electricity consumed under utility rate reform is:

$$
E_{C, R, S, t}=E_{R E S, R, S, t}\left(1-\varepsilon_{R, S, t} \times \Delta P_{C, R, S}\right)
$$

where

$C=$ scenario, which is either high $(H)$ or low $(L)$

$R=$ region, which is either Middle Atlantic (MA) or Pacific (P)

$S=$ sector, which is either Residential (R), Commercial (C) or Industrial (I).

$t=$ year; which is either 1985 or 2000

and

$$
\begin{aligned}
E_{C, R, S, t}= & \text { electricity consumed in year } t \text { in sector } S \text { in region } R \text { under } \\
& \text { assumptions of case } C . \\
E_{R E S, R, S, t}= & \text { electricity consumed in year } t \text { in sector } S \text { in region } R \text { as } \\
& \text { projected by } R E S . \\
= & \text { price elasticity for sector } S \text { in region } R \text { in year } t \text { where short- } \\
\varepsilon_{R, S, t} & \text { run elasticity is used in year } 1985 \text { and long-run elasticity is } \\
& \text { used in year } 2000 . \\
\Delta_{C, R, S=} & \text { change in price as a result of going to marginal cost pricing } \\
& \text { for sector } S \text { in region } R \text { under the assumptions of case } C .
\end{aligned}
$$

\subsubsection{Price Elasticities}

The price elasticies used in this analysis are shown in lables 3, 4 and $b$. Other estimates of price elasticity and values for income elasticity and crosselasticities for natural gas and $0 i 1$ are also shown. 


\section{TABLE 3. Electricity Demand Elasticities for}

the Residential Sector

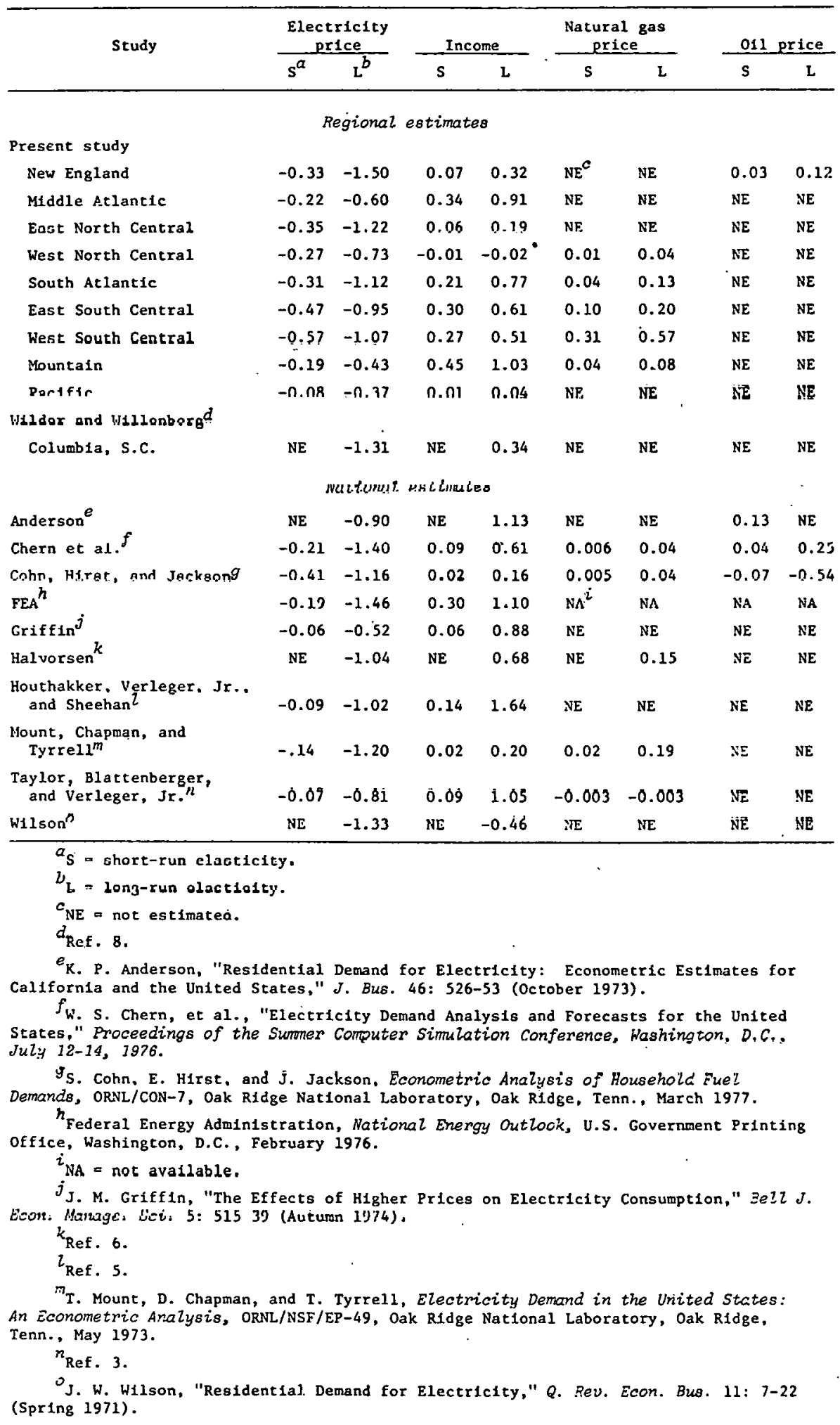


TABLE 4. Electricity Demand Elasticities for the Commercial Sector

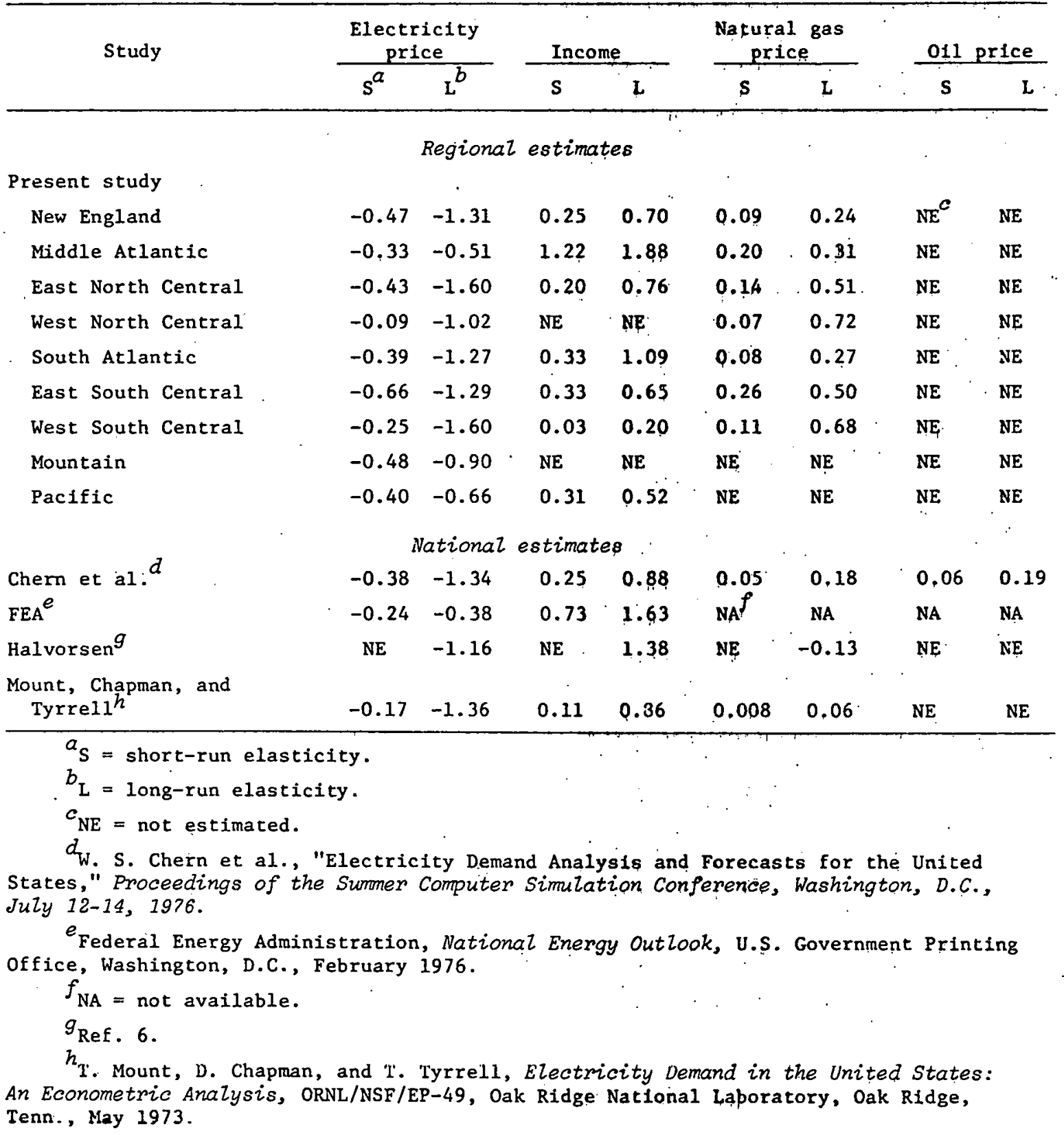

SOIIRC.E: Reference 1 
TABLE 5. Electricity Demand Elasticities for the Industrial Sector

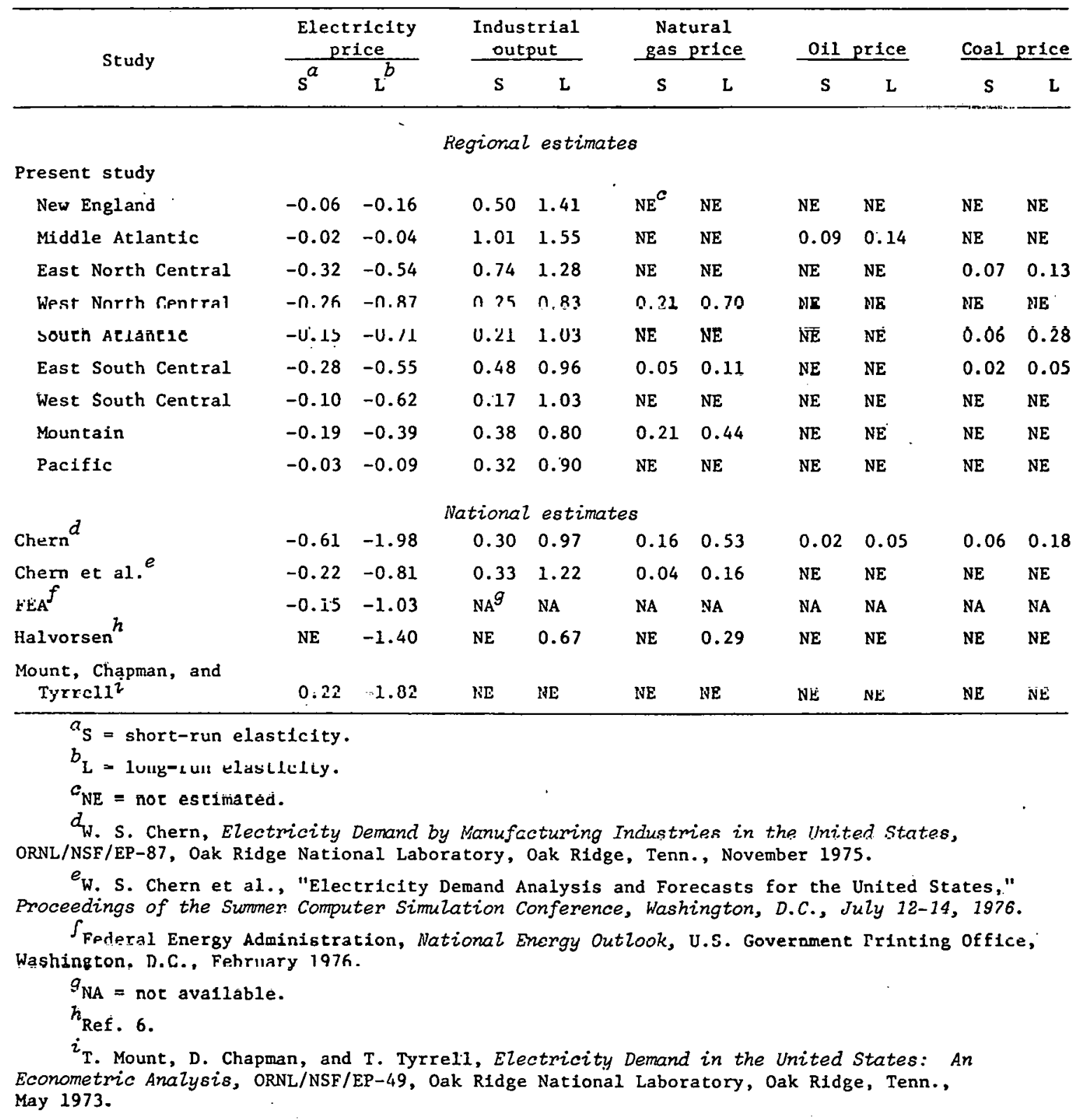

SOURCE: Reference 1 
These price elasticities must be used carefully. Basically, elasticity is a point concept, i.e., the ratio is only valid at one point along the demand curve. Usually it is an estimate over an arc of a given quantity or price change. Using the elasticity to measure consumption change over a larger range of price changes will lead to erroneous results. For example, a price elasticity of -0.60 implies that for a $1 \%$ price increase the consumer wi11 reduce demand by $0.6 \%(1 \times 0.6)$. But a doubling in price - a $100 \%$ increase - implies a $60 \%$ reduction in consumption. For a necessity like electricity such a radical reduction might be unrealistic. However, the unrealism is not with the use of the price elasticity but in the inherent assumption that the demand curve is linear over that large a price range.

Because of the above consideration it was deemed necessary to reduce some. of the elasticities when considering the types of price increases attributable to marginal pricing. The modified elasticities are shown in column 7 of Table 6 .

\subsubsection{Price Changes}

Estimates of regional price differences as a result of implementing marginal cost pricing are not readily available. In addition, it's not clear what estimates would be appropriate. Prior to 1970, marginal cost was usually below average cost. In 1972 the relationship began to change and based on some of the increases in the average price, the difference might be as high as $800 \%$. (a)

One national estimate of the difference is provided in the National Energy Plan II (Ref. 5), which indicates that replacement cost of delivered electricity is $16 \%$ greater than average priced electricity. This figure has been used together with intuitive judgments that incorporate 1) knowledge about regional differences in rate; 2) past and future trends, 3) assumptions that the RES model be treated as if a change in rate design happened in 1980 . Because of the uncertainty involved a low case and a high case were used to bound the problem. The percentage increases are shown below:

(a) It's useful to remember that increases in average cost will always be less than increases in marginal costs. 


$$
\text { Low Case High Case }
$$

$\begin{array}{lll}\text { Middle Atlantic } & 10 \% & 30 \% \\ \text { Pacific } & 20 \% & 50 \%\end{array}$

Note that the assumption of constant price is retained. Oniy a one time "jump" happens in 1980 to reflect the change in rate design. The Pacific region is higher due to its historically lower rates. The difference between residential and commercial rates was considered insignificant considering the quality of the data.

\subsubsection{Sector. Demand Changes}

The price leasticities and ahanges in price are used to estimate new projections for electricity consumption. Again the nature of this analys is implies that such a reduction occurs without any increases in the consumption of other fuels or increases in the production of other goods. Obviously this is unrealistic but it is useful for providing an upper bound on the benefits of utility rate reform.

Table 6 shows the data used, the modified projection for electricity consumed for each sector under the two cases (Column 9) and the percentage difference from the RES base case.

In the aggregate the numbers look plausible. The RES base case shows a $3 \%$ annual growth rate for the Pacific and $5 \%$ for the Middle Atlantic. Under the modified cases the annual growth rates are reduced to $1 \%$ and $4 \%$, respectively.

The only remaining data needed is estimates of the allocation of the savings indicated for the sector. to categories of end use like space heat, water heat, etc. The following percentages have been used to allocate the savings. 
TABLE 6. End-Use Sector Demard Changes in 1985 and 2000 under Low and High Case Assumptions for' Pacific and Middle Atlantic Regions

\begin{tabular}{|c|c|c|c|c|c|c|c|c|c|c|}
\hline & $\begin{array}{c}(1) \\
\text { Region }\end{array}$ & $\begin{array}{c}\text { (2) } \\
\text { Sector }\end{array}$ & $\begin{array}{l}(3) \\
\text { Year } \\
\end{array}$ & $\begin{array}{l}\text { (4) } \\
\text { Case } \\
\end{array}$ & $\begin{array}{l}(5) \\
\text { ERES } \\
\end{array}$ & $\begin{array}{l}(6) \\
\varepsilon \\
\end{array}$ & $\begin{array}{l}(7) \\
\varepsilon \\
\end{array}$ & $\begin{array}{l}(8) \\
\Delta P\end{array}$ & $\begin{array}{r}(9) \\
E_{C} \\
\end{array}$ & $\begin{array}{c}(5)-(9) \\
(5) \\
\Delta \% \\
\end{array}$ \\
\hline & Pacific & Residentici & 1985 & Low & 427.5 & -.08 & & .20 & 420.7 & -1.6 \\
\hline & & & & High & 427.5 & -.08 & & .50 & 410.4 & -4.0 \\
\hline & & & 2000 & Low & 699.2 & -.37 & -.30 & .20 & 657.2 & -6.0 \\
\hline & & & & $\mathrm{High}$ & 699.2 & -.37 & -.30 & .50 & 594.3 & -15.0 \\
\hline & & Commercial & 1985 & Low & 432.6 & -.40 & -.25 & .20 & 411.0 & -5.0 \\
\hline & & & & $\mathrm{High}$ & 432.6 & -.40 & -.25 & .50 & 378.5 & -12.5 \\
\hline & & & 2000 & Low & 625.7 & -.66 & -.40 & .20 & 575.6 & -8.0 \\
\hline & & & & $\mathrm{High}$ & 625.7 & -.66 & -.40 & .50 & 500.6 & -20.0 \\
\hline & & Industrial & 1985 & Low & 438.8 & -.03 & & .20 & 436.2 & -0.6 \\
\hline · & & & & High & 438.8 & -.03 & & .50 & 432.2 & -1.5 \\
\hline & & & 2000 & Low & 677.4 & -.09 & & .20 & 665.2 & -1.8 \\
\hline & & & & High & 677.4 & -.09 & & .50 & 646.9 & -4.5 \\
\hline & & Total & 1985 & Low & 1298.9 & . & & & 1267.9 & -7.2 \\
\hline & & & & High & 1298.9 & & & & 1221.1 & -18.0 \\
\hline 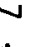 & & & 2000 & Low & 2002.3 & & & & 1898.0 & -15.8 \\
\hline 1 & & & & High & 2002.3 & & & & 1741.8 & -39.5 \\
\hline & Middle Atlantic & Residential & 1985 & Low & 502.7 & -.22 & & .10 & 491.6 & -2.2 \\
\hline & & & & High & 502.7 & -.22 & & .30 & 469.5 & -6.6 \\
\hline & & & 2000 & Low & 918.6 & -.60 & -.40 & .10 & 881.9 & -4.0 \\
\hline & & & & $\mathrm{High}$ & 918.6 & -.60 & -.40 & .30 & 808.4 & -12.0 \\
\hline & & Conmerciai & 1985 & Low & 408.2 & -.33 & -.25 & .10 & 398.0 & -2.5 \\
\hline & & & & High & 408.2 & -.33 & -.25 & .30 & 377.6 & -7.5 \\
\hline & & & 2000 & Low & 634.5 & -.51 & -.35 & .10 & 612.3 & -3.5 \\
\hline & & & & High & 634.5 & -.51 & -.35 & .30 & 567.9 & -10.5 \\
\hline & & Industrial & 1985 & Low & 565.1 & -.02 & & .10 & 564.0 & -0.2 \\
\hline & & & & High & 565.1 & -.02 & & .30 & 561.7 & -0.6 \\
\hline & & & 2000 & Low & 1534.4 & $-.0 n$ & & .10 & $1528.3^{\circ}$ & -0.4 \\
\hline & & & & High & 1534.4 & -.04 & & .30 & 1516.0 & -1.2 \\
\hline & & Total & 1985 & Low & 1476.0 & & & & 1453.6 & -4.9 \\
\hline & & & & High & 1476.0 & & & & 1408.8 & -14.1 \\
\hline & & & 2000 & Low & 3087.5 & & & & 3022.5 & -7.9 \\
\hline & & & & $\mathrm{High}$ & 3037.5 & & & & 2892.3 & -23.7 \\
\hline
\end{tabular}




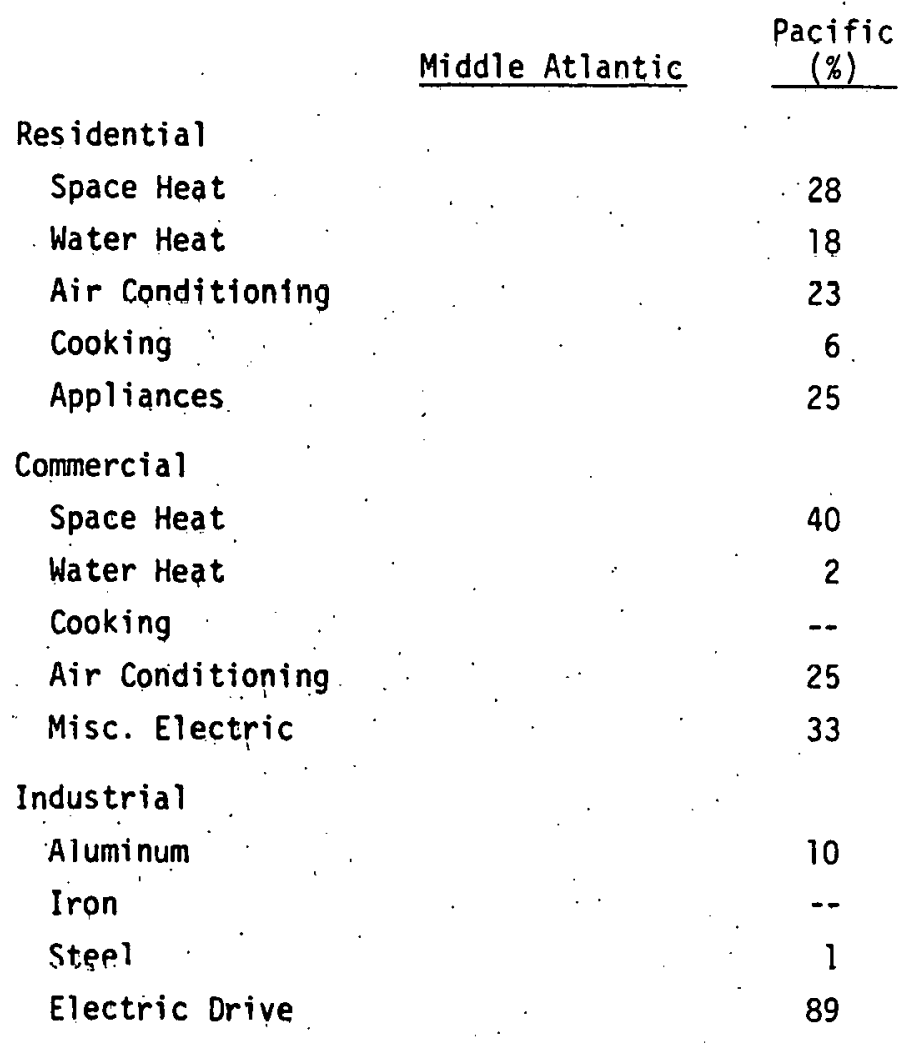




\subsection{CONCLUDING REMARKS}

The purpose of this exercise is to provide reasonable changes in end-use demand for electricity as a result of implementing a change in electric rate design. The data on end-use will then be used to estimate the environmental benefits of such a change. No attempt is made here to project electricity consumption in the years 1985 and 2000.

As noted previously, the methodology and assumptions used here cause the estimates of demand reduction to be on the high side, and do not allow for interfuel substitution. In addition, the lack of any empirical data on price elasticity for a large change in electrical rate is of concern. The use of the price elasticities over a large price change might be "stretching" the applicability of the data. Obviously, this all implies the need for caution in the interpretation and utilization of the data. 


\subsection{REFERENCES}

1. Chern, W. S., et al., Regional Econometric Model for Forecasting Electricity Demand by Sector and by State (NUREG/ER-0250, ORNL/NUREG-99) October 1978.

2. Hermelee; Alan, Regional Reference Energy Systems, EPRI EA-462, June 1977.

3. Taylor, Lester .D., "The Demand for Electricity: A Survey" in the Bell Journal of Economics, Spring 1975, pages 74-110.

4. National Research Counci1. Committee on Nuclear and Alternative Energy Systems, Synthesis Panel. Modeling Resource Group. Energy Modeling for an Uncertain Future: The Report of the Modeling Resource Group, Synthesis Panel of the Committee on Nuclear and Alternative Energy Systems, National Research Council--Washingțon: National Academy of Sciences, 1978.

5. National Energy Plan II, page VI-O. 